\title{
Developmentally-Inspired Biomimetic Culture Models to Produce Functional Islet-Like Cells From Pluripotent Precursors
}

\section{OPEN ACCESS}

Edited by:

Jose Moran-Mirabal,

McMaster University, Canada

Reviewed by:

Jeffrey R. Millman,

Washington University School of Medicine in St. Louis, United States

Chiara Magliaro,

University of Pisa, Italy

*Correspondence:

Corinne A. Hoes/

corinne.hoesli@mcgill.ca

Christopher Moraes

chris.moraes@mcgill.ca

tORCID:

Raymond Tran

orcid.org/0000-0002-1395-1038

Christopher Moraes orcid.org/0000-0002-8950-2212

Corinne A. Hoesli orcid.org/0000-0002-5629-7128

Specialty section:

This article was submitted to

Bionics and Biomimetics,

a section of the journal

Frontiers in Bioengineering and

Biotechnology

Received: 16 July 2020 Accepted: 08 September 2020

Published: 07 October 2020

Citation:

Tran R, Moraes $C$ and Hoesli CA

(2020) Developmentally-Inspired

Biomimetic Culture Models

to Produce Functional Islet-Like Cells

From Pluripotent Precursors.

Front. Bioeng. Biotechnol. 8:583970.

doi: 10.3389/fbioe.2020.583970

\author{
Raymond Tran ${ }^{1 \dagger}$, Christopher Moraes ${ }^{1,2 *}$ and Corinne A. Hoesli ${ }^{1,2 *}$ \\ ${ }^{1}$ Department of Chemical Engineering, McGill University, Montreal, QC, Canada, ${ }^{2}$ Department of Biomedical Engineering, \\ McGill University, Montreal, QC, Canada
}

Insulin-producing beta cells sourced from pluripotent stem cells hold great potential as a virtually unlimited cell source to treat diabetes. Directed pancreatic differentiation protocols aim to mimic various stimuli present during embryonic development through sequential changes of in vitro culture conditions. This is commonly accomplished by the timed addition of soluble signaling factors, in conjunction with cell-handling steps such as the formation of 3D cell aggregates. Interestingly, when stem cells at the pancreatic progenitor stage are transplanted, they form functional insulinproducing cells, suggesting that in vivo microenvironmental cues promote beta cell specification. Among these cues, biophysical stimuli have only recently emerged in the context of optimizing pancreatic differentiation protocols. This review focuses on studies of cell-microenvironment interactions and their impact on differentiating pancreatic cells when considering cell signaling, cell-cell and cell-ECM interactions. We highlight the development of in vitro cell culture models that allow systematic studies of pancreatic cell mechanobiology in response to extracellular matrix proteins, biomechanical effects, soluble factor modulation of biomechanics, substrate stiffness, fluid flow and topography. Finally, we explore how these new mechanical insights could lead to novel pancreatic differentiation protocols that improve efficiency, maturity, and throughput.

Keywords: pancreas, stem cells, mechanobiology, development, differentiation, microenvironment, islets

\section{INTRODUCTION}

Cell therapies involve the transplantation of human tissues or cells to treat illnesses that progressively damage or degrade functional tissues. These treatments are typically limited by access to a reliable and cost-effective cell source. For a successful transplant, allogeneic matching requires identification, procurement and transport of donor material; and variations in quality of the donated tissue may affect therapeutic potential. Therefore, the large-scale production of biological material for cell therapies is a rapidly growing area of interest. The primary goal of such research is to produce adequate quantities of functional therapeutic cells in a cost-effective manner.

Treatment of type 1 diabetes by islet transplantation is one example of a currently approved cell therapy. Here, donor islets are used to replace the insulin-secreting functionality lost from the 
autoimmune destruction of pancreatic beta cells. The Clinical Islet Transplantation Consortium trial (CIT-07) reported that $87.5 \%$ of patients were free from severe hypoglycemic events and achieved normal or near normal glycemic control at the 1 year end point (Foster et al., 2018). As with other cell therapies, the supply of donor islets greatly limits availability of this treatment. Islet transplantation typically requires a dose of greater than 5000 islet equivalents (IE) per kg body weight (Shapiro et al., 2017). To achieve the 500,000-1,000,000 IE/patient, islets are typically pooled from multiple deceased donors. Furthermore, the viability and function of the recovered islets is dependent on extraction techniques and post-mortem handling (Rosenberg et al., 1999; Paraskevas et al., 2000; Negi et al., 2012).

The production of insulin-secreting beta-like cells from pluripotent stem cells (PSCs) is a potential solution to the donor supply issues of islet transplantation. The first report of stem-cell derived insulin-producing cells via spontaneous differentiation was almost two decades ago and reported only 1-2\% insulin ${ }^{+}$cells (Assady et al., 2001). However, subsequent studies demonstrated that insulin staining and glucose-stimulated release can be due to insulin uptake from cell culture media (Rajagopal et al., 2003; Hansson et al., 2004; Sipione et al., 2004). Therefore, later studies reported C-peptide and/or pro-insulin content as well as more careful assessment of function and insulin granules instead of just insulin as a marker (Sipione et al., 2004; D'Amour et al., 2006; Naujok et al., 2009). More recent developments have been more successful, and rely on directed differentiation protocols which involve guiding stem cells through stages of pancreas development by mimicking the soluble signals present in vivo. These protocols are long and typically last more than 20 days (Rezania et al., 2014; Millman et al., 2016; Nair et al., 2019; Hogrebe et al., 2020). One of the first major breakthroughs was homogenous induction of PSCs into the endoderm lineage (up to $80 \%$ endoderm cells) (D'Amour et al., 2005) and subsequently into cell populations with significant C-peptide and proinsulin content (D'Amour et al., 2006). Since then, the efficiency of monohormonal beta cell induction has increased $\left(\sim 40 \% \mathrm{NKX} 6.1^{+} / \mathrm{C}\right.$-peptide $\left.{ }^{+}\right)$(Hogrebe et al., 2020). However, producing functional cell populations from PSCs remains an issue (Pagliuca et al., 2014; Rezania et al., 2014; Velazco-Cruz et al., 2019, 2020; Veres et al., 2019). Maturation of PSC-derived pancreatic progenitors can be accomplished when transplanted in vivo (Rezania et al., 2012; Robert et al., 2018) but typically requires cell aggregation in vitro (Toyoda et al., 2015; Nair et al., 2019). Hence, current strategies to improve directed differentiation protocols involve optimizing the duration of each differentiation stage as well as incorporating various aspects of the developmental microenvironment (Nostro et al., 2015; Mamidi et al., 2018; Nair et al., 2019; Hogrebe et al., 2020).

This review will primarily focus on recent biomimetic approaches which exploit biochemical and biomechanical cues to promote the differentiation of pancreatic cells. We will first address directed differentiation protocols relying on soluble factors, followed by a discussion of more recent advances which mimic biophysical features of the developmental microenvironment, by manipulating cell-cell or cell-substrate interactions.

\section{DIRECTED PANCREATIC DIFFERENTIATION AND CELL SIGNALING}

Directed differentiation is the process of guiding stem cells through development to produce a desired, mature cell population. Classically, this is done by the timed addition of soluble factors to mimic conditions present during stages of development. In the context of pancreatic beta cell manufacturing, protocols emulate the multistep transition from pluripotent stem cells to definitive endoderm lineage, then toward the specification of the primitive gut tube and the subsequent pancreatic developmental steps (Figure 1A) (Pan and Wright, 2011; Benitez et al., 2012; Jennings et al., 2015; Dassaye et al., 2016). Each stage of development is accompanied by the nuclear expression of key transcription factors such as PDX1 or NKX6.1, which are commonly accepted as the first pancreatic and beta cell lineage markers respectively (Figure 1B) (Offield et al., 1996, 1; Schaffer et al., 2013, 1). Ultimately, the end goal of these protocols is to produce monohormonal, insulin-producing cells that have glucose-sensing capability comparable to native islets.

In addition to soluble biochemical signals, other components of the cellular microenvironment are known to play a critical role during embryonic development. Stimuli from the microenvironment include biophysical cell-cell interactions and cell-extracellular matrix (ECM) interactions (Discher et al., 2009), which can interact with soluble factor signaling in a synergistic manner. However, the in vivo microenvironment, particularly during embryonic development, is particularly complex and difficult to mimic with current knowledge and culture systems.

Embryonic development is guided via highly dynamic signals from the surrounding cell microenvironment with remarkable precision and robustness. As cells differentiate, they relay different signals to neighboring cells by secreting soluble factors and matrix proteins. The soluble signaling cues associated with pancreatic differentiation have been well-studied using animal models and include the Wnt, Activin/Nodal, fibroblast growth factor (FGF), bone morphogenetic protein (BMP), retinoic acid, and sonic hedgehog (Shh), and Notch signaling pathways (Hashemitabar and Heidari, 2019). However, relatively little attention has been paid to the physical stimuli present during embryonic development. Biomechanics and cell/tissue mechanobiology play a large role in guiding cell behavior especially during early embryogenesis (Heisenberg and Bellaïche, 2013). The pathways through which biomechanical cues translate to differentiation are not as well-understood in vivo. Studies of developmental mechanobiology are challenging, and these parameters are often not considered as it is unclear what mechanics are present during human embryogenesis. Furthermore, the complexity of the in vivo microenvironment makes it difficult to control these biomechanical signals and to delineate their effects on differentiation from other correlated 
A

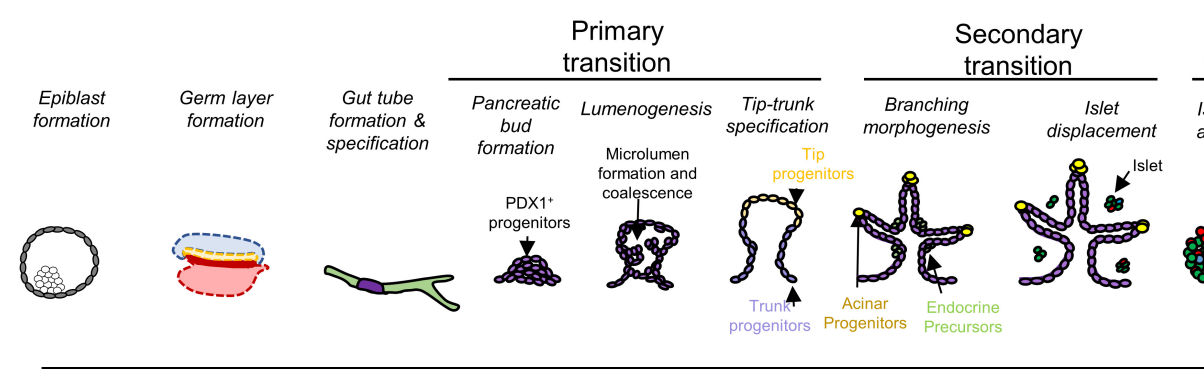

Tertiary

transition

Islet maturation and remodeling

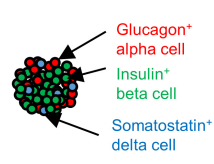

Developmental time

B

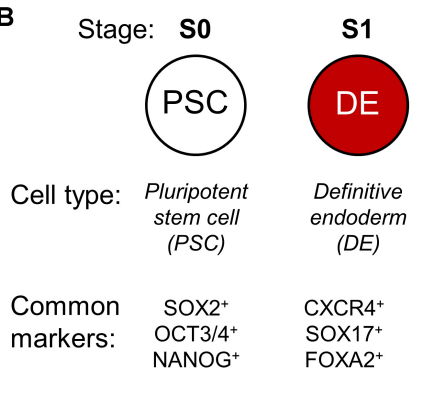

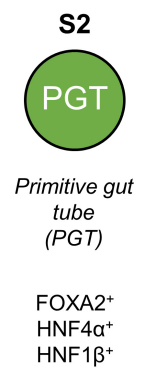

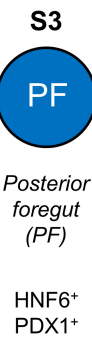

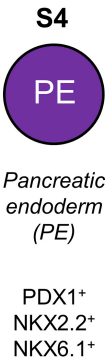

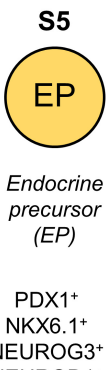

NEUROG3+

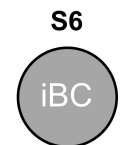

Immature beta cell $(i B C)$

PDX1+
NKX6.1
NEVRDO1+ NKX6.1+ NEURDO1+

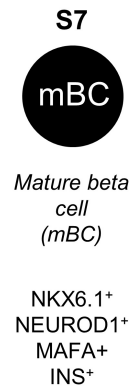

FIGURE 1 | (A) Illustrative schematic of pancreas development which is characterized by three main transitions. Primary transition involves bud formation and specification of different pancreatic cell types. Secondary transition involves branching of the pancreatic bud, further specification of endocrine precursors, and the delamination of islet cells. Tertiary transition involves remodeling of islet architecture and further maturation (Pan and Wright, 2011; Benitez et al., 2012; Jennings et al., 2015; Dassaye et al., 2016). (B) Directed differentiation protocols recreate stages of differentiation in a step-by-step manner and look for expression of key transcription factors. Based on data presented by Rezania et al. (2014).

stimuli. Therefore, the field relies mainly on studies of biochemical pathways with in vivo mouse models or in vitro human models for information.

Cells respond to mechanical stimuli through mechanotransduction mechanisms, in which biomechanical stimuli are converted into biochemical signals (Chen, 2008; Moraes et al., 2011; Martino et al., 2018; Wolfenson et al., 2019). Reciprocally, cells alter the mechanics of their surrounding tissues by exerting contractile forces (Wozniak and Chen, 2009; Wang H. et al., 2014) and depositing or degrading the ECM proteins (Rozario and DeSimone, 2010; Bonnans et al., 2014). External biomechanical stimuli can promote cytoskeletal reorganization and subsequent changes in protein activity or localization, gene expression (Wang et al., 2009), proliferation (Frank et al., 2016), and differentiation (Saha et al., 2006; Fang et al., 2019). Mechanotransduction could occur via mechanosensitive pathways such as Hippo signaling (Piccolo et al., 2014) which is heavily involved in development by regulating tissue growth (George et al., 2012), death (Sharma et al., 2017), and cell fate (RosadoOlivieri et al., 2019). Properly designed novel cell culture substrates to control these aspects of cell-cell and cellenvironment interactions could help drive cells toward desired cell fates. Biomechanical cues could be incorporated into cell culture systems to reduce the cost of soluble factors added in differentiation or the time required to produce a desired cell type. Therefore, in the following sections, we review the interactions between cells and biophysical components in the developmental microenvironment, to build a roadmap towards more advanced beta stem cell specification platforms (Figure 2).

\section{CELL-CELL INTERACTIONS}

Resident cells communicate with their neighbors during development by secreting soluble signaling molecules which can bias differentiation (Basson, 2012). The developmental microenvironment contains multiple transient cell types which each have different roles in the differentiation process. Within this environment, cells actively uptake soluble signaling factors and nutrients to form concentration gradients which are dependent on tissue thickness, vascularization, and oxygenation. In each of the following sections, we describe approaches to pancreatic differentiation that rely on controlling the soluble factor environment, optimizing cell seeding density, and forming pancreatic aggregates, all of which mimic aspects of developmental processes.

\section{Soluble Factor-Based Directed Differentiation}

The in vivo cellular microenvironment is much more intricate than can be modeled by current in vitro systems. Although directed differentiation protocols that focus solely on the 


\section{CELL-CELL INTERACTIONS}

\section{CELL-MATRIX INTERACTIONS}

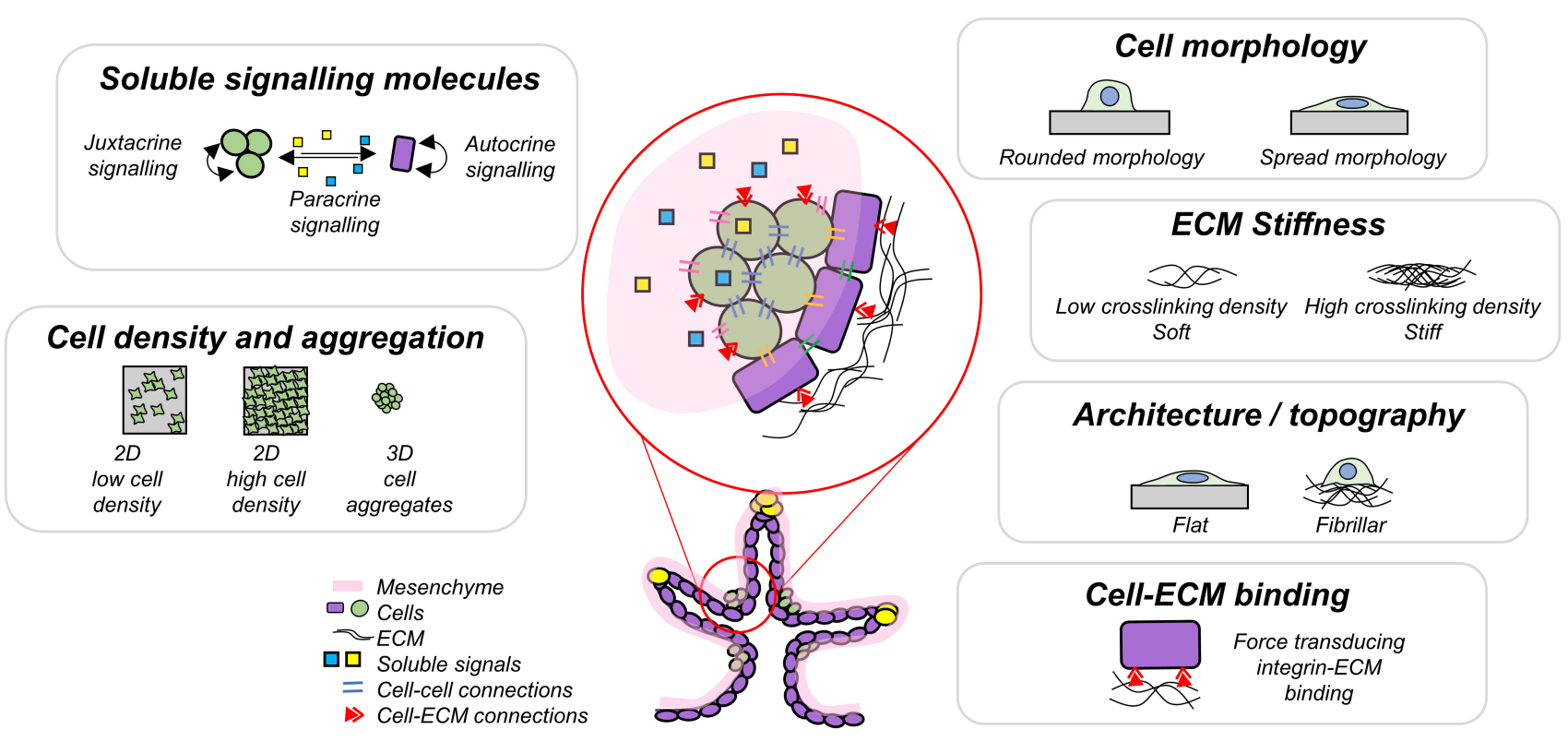

FIGURE 2 | Summary of some cell interactions present during pancreas development which may play a role in guiding endocrine differentiation.

timed addition of soluble signaling factors can generate insulin-producing cells (Pagliuca et al., 2014; Rezania et al., 2014; Millman et al., 2016; Yung et al., 2019; Hogrebe et al., 2020), these protocols typically produce some polyhormonal cells which have a transcriptome similar to fetal beta cells (Hrvatin et al., 2014), while monohormonal insulin-producing cells are more similar to adult pancreatic beta cells (Pagliuca et al., 2014). This may explain why earlier protocols produced cells with impaired glucose-sensing capabilities (Rezania et al., 2014), which may be due to metabolic bottlenecks in glycolysis (Davis et al., 2020). Furthermore, variation in differentiation efficiency between PSC lines (Osafune et al., 2008; Nostro et al., 2015) and in handling procedures between research groups represents a significant challenge for clinical translation. Interestingly, when immature NKX6.1 $1^{+}$pancreatic progenitors are transplanted into immunocompromised mice, they form functional insulin-producing cells (Kroon, 2008; Rezania et al., 2012) and are able to provide long-term glycemic control when encapsulated within immunoprotective alginate polymers (Vegas et al., 2016). This suggests that some missing elements of the in vivo microenvironment have the potential to further improve mature beta cell production for therapeutic use.

The presence of other cell types found in native islets can improve insulin response. Glucose-stimulated insulin secretion is regulated by paracrine glucagon signaling from neighboring alpha cells (Samols et al., 1965; Trimble et al., 1982; Kelly et al., 2011; Svendsen et al., 2018). Human islets that are dispersed and reaggregated into controlled-size aggregates can restore glycemic control in diabetic mice, suggesting that functional insulin response can be achieved with the appropriate co-culture (Yu et al., 2018). Soluble factors from mesenchymal stromal/stem cells (MSCs) in Transwell ${ }^{\circledR}$ cultures also improves proliferation, pancreatic differentiation, and engraftment function via IGF1 signaling ( $\mathrm{Li}$ et al., 2019). The presence of human amniotic epithelial cells within islet organoids grafted into a type 1 diabetes mouse model had enhanced blood glucose control and increased percentage diabetic reversal (96 vs. 16\%) after 1 month compared to animals transplanted with only islet cells (Lebreton et al., 2019). In directed differentiation, the addition of endothelial cells has also been shown to induce maturation of hESCderived pancreatic progenitor cells toward insulin-expressing cells (Jaramillo et al., 2015). Overall, the addition of other cell types may improve current differentiation protocols, but it is currently not well-understood whether these effects originate from paracrine signaling or cell-cell contacts.

Cell proliferation and other cell attributes such as metabolic rates can change the soluble factor microenvironment, including the level of dissolved oxygen available to cells. Control of oxygen and other nutrient levels therefore might be a useful strategy to improve cell functionality. Beta cells have a high oxygen demand and the oxygenation of islets is critical for survival (Komatsu et al., 2017) and function (Ludwig et al., 2012). Differentiation of PSCs under increased oxygen tension promoted differentiation into pancreatic progenitors and subsequently, insulin-producing cells over normoxic conditions (Heinis et al., 2010; Hakim et al., 2014). Bioreactors providing feed-back control over nutrient and other biomolecular concentrations could improve the reproducibility of PSC pancreatic differentiation protocols. 


\section{Cell Density Effects on Differentiation and Function}

Regulation of cell density is paramount to achieve controlled differentiation toward the desired cell lineage. High initial cell seeding densities promotes the differentiation of PSCs into definitive endoderm cells (Gage et al., 2013) as well as into downstream endocrine lineages (Takizawa-Shirasawa et al., 2013). Pancreatic differentiation arising from high cell density protocols is correlated with the downregulation of Rhoassociated kinases (ROCK) and non-muscle myosin II (NM II) mRNA and proteins. This effect was independent of cell proliferation. At similar cell densities, inhibition of ROCK-NM II pathways improved pancreatic differentiation over controls, suggesting that this effect is due to aggregation (Toyoda et al., 2017). High cell density cultures may therefore better recapitulate the local cell density in the developing pancreas, thereby increasing bias toward pancreatic endocrine fate. The mechanism by which high density cultures promotes pancreatic differentiation may include increased cell-to-cell contact, changes in oxygen tension, or increased soluble factor signaling. While the exact mechanisms remain to be elucidated, this general approach may be valuable for pancreatic differentiation protocols.

\section{Cell Aggregation \\ Effects of Cell Aggregation on Beta Cell Differentiation and Function}

Forcibly aggregating pancreatic cells could capture many of the effects of high density culture, and may also better mimic the 3D environment and cell-cell signaling found in vivo to ultimately produce a more relevant phenotype in vitro (Antoni et al., 2015; Hohwieler et al., 2017; Glieberman et al., 2019). In vitro, spontaneous, cell-mediated clustering of pancreatic endoderm cells has been observed in 2D cultures (Nostro et al., 2015; Tran et al., 2020). A potential candidate driving this clustering behavior in vivo is the secretion and chemotaxis of FGF2, which further promotes differentiation into hormone producing, islet-like clusters (Hardikar et al., 2003). Thus, most directed differentiation protocols to generate functional beta-like cells rely on culturing differentiating and maturing pancreatic endoderm cells as aggregates (Pagliuca et al., 2014; Nair et al., 2019). The benefits of forced aggregation in directed differentiation may have origins in the biomimicry of pancreatic development where cell clusters are formed in primary transition and islet clustering.

Cell aggregation is important for proper functionality of beta cells (insulin response to glucose challenges) perhaps due to improved paracrine signaling and cell-cell contacts (Chowdhury et al., 2013; Lecomte et al., 2016). Paracrine signaling is necessary for proper crosstalk between the various hormonal cells (alpha, beta, delta, gamma cells) in native islets (Caicedo, 2013). Insulin secretion is also aided by calcium-driven electrical coupling of islet cell clusters (Pedersen et al., 2005; Sabatini et al., 2019). PSC-derived pancreatic aggregates encapsulated within a 3D matrix showed increased insulin secretion after 6 days compared to encapsulated single cells and cells cultured on a flat $2 \mathrm{D}$ surface, suggesting these functionalities may be closely linked to aggregation and paracrine signaling (Kim et al., 2019). Forced aggregation of PSC-derived pancreatic progenitor cells increases the proportion of NKX6.1 $1^{+}$cells over standard 2D cultures (Toyoda et al., 2015). In their later work, Toyoda et al. (2017) demonstrated that inhibition of Rho-associated kinases (ROCK) and non-muscle myosin II (NM II) increased the fraction of NKX6.1 $1^{+}$cells by emulating an aggregate phenotype even in low density cultures, suggesting that the physical act of aggregation may not be necessary. In addition to this, recent studies have shown that insulin-secreting cells can be produced in planar, nonaggregate protocols by the timed depolymerization of the actin cytoskeleton (Hogrebe et al., 2020).

\section{Technologies to Study Cell Aggregation}

Proper control of aggregate size is an important design consideration since mass transfer limitations arise in larger aggregates and gradients in soluble signaling factors begin to play a role in specification. In vitro, larger non-vascularized islets may develop central necrosis due to high metabolic demand and low oxygenation (Avgoustiniatos and Colton, 1997; Komatsu et al., 2017). To avoid core hypoxia, finite element models can be used to determine the optimal aggregate size in suspension (Buchwald, 2009) and encapsulation systems (Avgoustiniatos and Colton, 1997; Song and Millman, 2016). The average diameter of human islets is around 100-400 $\mu \mathrm{m}$ (Hellman, 1959; Suszynski et al., 2014; Ionescu-Tirgoviste et al., 2015). When islets and stem cell-derived beta cells are dissociated and re-aggregated, the optimal diameter to maintain viability and function was shown to be 100-150 $\mu \mathrm{m}$ (Hilderink et al., 2015; Song and Millman, 2016) while also improving survivability and function, perhaps due to improved nutrient availability (Yu et al., 2018). Therefore, creating aggregates of uniform size is crucial for reproducible production of functional insulin-producing cells.

Several groups have developed methods to reproducibly create endocrine cell aggregates of defined size to improve functionality (Gao et al., 2019; Nair et al., 2019; Velazco-Cruz et al., 2019). Culturing pancreatic cells on microporous scaffolds can improve differentiation toward insulin secreting beta-like cells over suspension cultures by guiding formation of consistently sized aggregates (Youngblood et al., 2019). Physical confinement of 3D MIN6 aggregates in 2\% alginate beads promotes glucosestimulated insulin secretion but decreases proliferation compared to adherent 2D culture (Hoesli et al., 2011). Micropatterned culture can be used to promote cell-driven clustering of PSCderived NKX6.1 $1^{+}$cells with defined sizes while maintaining ease of handling associated with 2D cultures. Clustered cells from micropatterned confinement have increased PDX1 and NKX6.1 protein expression when compared to unconfined cells and this effect was further correlated with local cell density increases (Tran et al., 2020). Agarose microwells (Hilderink et al., 2015), pyramid-shaped polystyrene wells (Ungrin and Zandstra, 2011), or hydrogel micropockets (Zhao et al., 2019) have also been used to generate cell aggregates of controlled size. The production of uniformly sized cell aggregates in a scalable matter may be the key to producing mature cells for cell therapies in a consistent manner. Within these aggregates, cells deposit insoluble ECM proteins and dynamically change the surrounding microenvironment, which suggests that the architecture of these 
clusters and in general, the surrounding surfaces could play a large role in differentiation.

\section{CELL-MATRIX INTERACTIONS}

The ECM presents cues to surrounding cells in the form of biochemical signals, growth factors, and biophysical signals (Nakayama et al., 2014). Native ECM found in vivo is extremely complex and contains 100s of different proteins with varying composition depending on region. Combinatorial protein arrays are useful to study the interactive and additive effects of different ECM components on stem cell behavior (Flaim et al., 2005; Alberti et al., 2008; Guilak et al., 2009; LaBarge et al., 2009). However, the architecture of native ECM is equally important and also plays a role in guiding stem cell differentiation through cellgenerated force feedback mechanisms (Trappmann et al., 2012). In the developing embryo, the ECM structure and composition is dynamically evolving, which constantly changes the biochemical and biophysical cues presented to developing cells (Rozario and DeSimone, 2010). Understanding the different aspects of the ECM and their role in differentiation during each stage of pancreas development (Table 1) could help the development of novel biomimetic culture systems to better guide the production of functional insulin-secreting cells.

\section{Biochemical Effects of ECM Proteins}

The presence of ECM proteins produced within a cell and ECM pre-adsorbed or conjugated onto culture substrates, is essential for successful differentiation. These proteins can also bind growth factors which can affect presentation to the cells and improve growth factor stability (Taipale and Keski-Oja, 1997; Belair et al., 2014). The ECM components of the microenvironment can influence survival, adhesion, proliferation, and guide downstream cell fate decisions (Guilak et al., 2009; Gattazzo et al., 2014). The ECM of the human adult islet is composed mainly of laminin, collagen IV, fibronectin, and other types of collagen; whereas the embryonic pancreas ECM is fundamentally distinct and is primarily comprised of vitronectin, fibronectin, and collagen IV (Stendahl et al., 2009). Designing cell culture systems with combinations of ECM proteins found in the pancreas could therefore help improve pancreatic cell function and differentiation (Table 1, Column 5).

Several works have shown that islets and other pancreatic cells have improved functionality when cultured in matrices that recapitulate those found in vivo. Collagen and fibronectin have been shown to promote beta cell survival, while laminins are responsible for beta cell specification and insulin secretion (Arous and Wehrle-Haller, 2017). Islets encapsulated in hydrogels containing collagen IV and laminin show improved glucosestimulated insulin secretion response (Weber and Anseth, 2008; Kim et al., 2019). Incorporating ECM-derived peptides such as RGD, LRE, PDSGR has also been shown to improve viability and glucose-stimulated insulin secretion in alginate encapsulated islets (Llacua et al., 2016; Medina et al., 2020).

Coating cell culture substrates with ECM proteins to mimic the biochemical effects of the ECM can guide directed differentiation of PSCs toward the endocrine lineage. Directed differentiation of PSCs in 2D conditions usually begins on a Matrigel-coated surface (Rezania et al., 2014; Hogrebe et al., 2020; Tran et al., 2020). However, Matrigel suffers from batch-to-batch variability which could affect differentiation outcomes. Purified ECM proteins (Amit et al., 2004; Ludwig et al., 2006), recombinant proteins (Chen et al., 2011; Wang Y. et al., 2014), or synthetic matrices (such as functionalized polyethylene glycol (PEG) or alginate) (Aisenbrey and Murphy, 2020) could serve as alternatives to Matrigel for PSC maintenance. Synthetic matrices and recombinant protein alternatives require more study in the context of pancreatic differentiation. Therefore, understanding the effect of constituent proteins in Matrigel and their effect on pancreatic differentiation is a necessary step to effectively guide differentiation outcomes. The synergistic role of various ECM protein mixtures can be screened combinatorically using protein arrays thus allowing for optimization of pancreatic differentiation protocols. For example, PSCs cultured on substrates coated with collagen I or in combination with collagen II and fibronectin reduced the time required for high purity endoderm differentiation (Rasmussen et al., 2016a). Fibronectin has previously been shown to downregulate the pluripotency of PSCs and enhance endoderm differentiation, which leads to the pancreatic lineage downstream (Brafman et al., 2013; Taylor-Weiner et al., 2013). Combinations of the main pancreatic ECM components, including fibronectin, collagen IV, and laminin, further promote ESC differentiation into pancreatic lineages (Narayanan et al., 2013; Malta et al., 2016). Further downstream, the composition of ECM protein coatings can also guide pancreatic cell fate decisions. Fibronectin-coated surfaces promote differentiation to ductal lineage whereas adhesion onto laminin-coated surfaces guides endocrine differentiation into $\mathrm{NGN}^{+}$cells (Mamidi et al., 2018).

Although Matrigel alternatives can be used to promote the initial stages of differentiation, downstream cell types may require a more complex environment. Embryonic murine pancreatic progenitors cultured in Matrigel gels could form organoid structures but not on synthetic 3D matrix alternatives (Greggio et al., 2013). PEG-based hydrogels functionalized with laminin 1 facilitated maintenance and expansion of murine pancreatic progenitors but on non-functionalized synthetic hydrogels, murine pancreatic progenitors did not expand and lost pancreatic character (Greggio et al., 2013). Similarly, bioinert PEG hydrogels maintained the viability of rat-derived pancreatic progenitors for 7 days, but failed to obtain glucoseresponsive behavior, further suggesting the importance of ECM interaction (Mason and Mahoney, 2008; Amer et al., 2015). Pancreatic progenitor cells isolated from adult murine pancreas can also be cultured in methylcellulose (Jin et al., 2016) or laminin gels (Jin et al., 2013) to generate insulinpositive cells.

Separating the principal components of the ECM may lead to more efficient and cost-effective differentiation but synergistic effects of the complete matrix may be lost. Differentiation could be improved by using decellularized 
TABLE 1 | Compiled effects of substrate stiffness and architecture on various pancreatic differentiation platforms.

\begin{tabular}{|c|c|c|c|c|c|c|}
\hline Author & Cell type & $\begin{array}{l}\text { Differentiation Platform } \\
\text { type }\end{array}$ & $\begin{array}{l}\text { ECM } \\
\text { coating }\end{array}$ & $\begin{array}{c}\text { Apparent } \\
\text { modulus } \\
(\mathrm{kPa})\end{array}$ & $\begin{array}{l}\text { Cell } \\
\text { morphology }\end{array}$ & $\begin{array}{l}\text { Relative } \\
\text { stiffness }\end{array}$ \\
\hline
\end{tabular}

\section{Architecture}

Ghanian et al., hESCs 2015

Directed

$\mathrm{SO} \rightarrow \mathrm{S} 1$

Electrospun

poly( $\varepsilon$-caprolactone $)$

Matrigel Not reported Clumped

Tissue culture polystyrene Matrigel (control)

Maldonado

iPSCS

Directed

SO $\rightarrow$ S3

et al., 2017

SO $\rightarrow$ S3

Electrospun

poly( $\varepsilon$-caprolactone)

Col I

$3 \times 10^{6 *}$

Spread

Stiff

Round, 3D colonies +

Electrospun

Col I

polyether-ketone-ketone

300

Spread

flattened 2D

Tissue culture polystyrene Col I

(control)

Substrate stiffness

et al., 2013

hESCS

Spontaneous

differentiation

Hyaluronic acid hydrogels Col IV, Fn, Lam

Tissue culture polystyrene RIN5F ECM (control)

Rasmussen hESCs Directed

et al., 2016b

$\mathrm{SO} \rightarrow \mathrm{S} 3$

High aspect ratio

polycarbonate nanopillars

colonies +

$3 \times 10^{6 *}$

1.3-3.5 Not reported

$3 \times 10^{6 *} \quad$ Not reported

clusters.
Narayanan hESC

Soft

34.6 Small, tight 2D Soft

Elongated and aligned with nanopillars

$\begin{array}{lllll}\begin{array}{l}\text { Low aspect ratio } \\ \text { polycarbonate nanopillars }\end{array} & \text { Fn } & 2800 & \text { Spread } & \text { Stiff } \\ \begin{array}{l}\text { Tissue culture polystyrene } \\ \text { (control) }\end{array} & \text { Fn } & 3 \times 10^{6 *} & \text { Spread } & \text { Stiff } \\ \begin{array}{l}\text { Low concentration barium } \\ \text { alginate capsules }\end{array} & \text { N/A } & 3.9 \pm 1.3 & \text { Larger circular } & \text { Soft } \\ & & & \text { 3D colonies } & \end{array}$

Kim et al., 2019 Rat islets Directed and PSCs $\mathrm{SO} \rightarrow \mathrm{S} 7$
High concentration barium N/A alginate capsules
dECM bio-ink

$$
\text { Human }
$$

pdECM

\section{$73.2 \pm 22.4$ Small, growth Stiff restricted $3 D$ colonies and large, elongated 3D colonies 3 Not reported -}

Collagen gel Col I Tissue culture polystyrene (control)
hESCs cultured on small diameter nanofibers adopted a clumped morphology and had improved definitive endoderm differentiation.

"Soft" nanofibers promoted posterior foregut and pancreatic differentiation. "Stiff" surfaces promoted mesodermal differentiation while downregulating pancreatic differentiation.

Optimal differentiation with $2.1 \mathrm{kPa}$ gels and a 1/3/3 mixture of Col IV, fibronectin, and laminin.

Poor hESC adhesion on soft nanopillars. "Soft" surfaces promoted endoderm (S1) differentiation. Control had significantly higher PDX1 protein expression (S3) compared to test conditions.

"Soft" capsules increase hESC proliferation and were highly PDX1+ (S3). Localized deposition of Col I and Lam in "soft" capsules. "Stiff" capsules support endodermal (S1) differentiation but downregulates pancreatic differentiation.

Insulin secretion and maturation were enhanced in cells cultured in pdECM bioinks compared to 2D tissue culture polystyrene (TCPS), alginate gels, and collagen gels 
TABLE 1 | Continued

\begin{tabular}{|c|c|c|c|c|c|c|c|c|}
\hline Author & Cell type & $\begin{array}{l}\text { Differentiation } \\
\text { type }\end{array}$ & Platform & $\begin{array}{l}\text { ECM } \\
\text { coating }\end{array}$ & $\begin{array}{l}\text { Apparent } \\
\text { modulus } \\
(\mathrm{kPa})\end{array}$ & $\begin{array}{l}\text { Cell } \\
\text { morphology }\end{array}$ & $\begin{array}{l}\text { Relative } \\
\text { stiffness }\end{array}$ & Impact \\
\hline \multirow[t]{2}{*}{$\begin{array}{l}\text { Hogrebe et al., } \\
2020\end{array}$} & PSCs & $\begin{array}{l}\text { Directed } \\
\text { SO } \rightarrow \text { S7 }\end{array}$ & Tall collagen I gel & Col I & $\mathrm{N} / \mathrm{A}$ & Not reported & Soft & $\begin{array}{l}\text { Decreased stiffness via increasing } \\
\text { gel height promotes overall } \\
\text { endocrine induction (increases } \\
\text { NGN3, NKX2.2, NEUROD1 and } \\
\text { decreases SOX9, NKX6.1 } \\
\text { expression) }\end{array}$ \\
\hline & & & Short collagen I gel & Col I & $\mathrm{N} / \mathrm{A}$ & Not reported & Stiff & \\
\hline \multirow[t]{2}{*}{$\begin{array}{l}\text { Pennarossa } \\
\text { et al., } 2018\end{array}$} & $\begin{array}{l}\text { Mouse } \\
\text { dermal } \\
\text { fibroblasts }\end{array}$ & Transdifferentiation & $\begin{array}{l}\text { Polyacrylamide } \\
\text { hydrogels }\end{array}$ & Coll & 0.1 & $\begin{array}{l}\text { 2D epithelioid } \\
\text { structure in } \\
\text { small, scattered } \\
\text { clusters }\end{array}$ & Soft & $\begin{array}{l}\text { Improved transdifferentiation } \\
\text { toward monohormonal pancreatic } \\
\text { endocrine cells on soft substrates }\end{array}$ \\
\hline & & & $\begin{array}{l}\text { Tissue culture } \\
\text { polystyrene } \\
\text { (control) }\end{array}$ & Coll & $3 \times 10^{6 *}$ & $\begin{array}{l}\text { 3D spherical } \\
\text { structures }\end{array}$ & Stiff & \\
\hline
\end{tabular}

Fn, fibronectin; Lam, laminin; Col, collagen; pdECM, pancreatic decellularized extracellular matrix. *Stiffness of polystyrene shown for reference taken from Gillbert et al. (2010). ${ }^{+}$Cell morphology details taken from previous work from same group (Maldonado, 2015).

pancreatic ECM (dpECM), thus retaining ECM proteins composition. Utilizing decellularized pancreas matrix scaffolds in bioartificial pancreas designs could also be a fruitful strategy to improve islet functionality by retaining pancreas stiffness and matrix architecture (Goh et al., 2013; Guruswamy Damodaran and Vermette, 2018). Hydrogels composed of decellularized human pancreata can support the proliferation and differentiation of pancreatic progenitors into insulinpositive cells (Wan et al., 2017; Sackett et al., 2018). Pancreatic tissues derived from iPSC cultured in 3D bioprinted inks primarily composed of dpECM had increased Pdx1, insulin, and glucagon expression compared to collagen controls (Kim et al., 2019). Cell culture with the addition of collagen $\mathrm{V}$, which was present in dpECM but not in Matrigel, enhanced islet organoid generation and glucose-responsive function (Bi et al., 2020). Overall, designing cell culture systems which recapitulate the in vivo ECM protein landscape could have significant impact to produce functional PSCderived beta cells.

In addition to the combinatorial effects of individual ECM components, the composition of the ECM is dynamically changing during development. While one composition may promote early pancreatic differentiation, the same composition may hinder downstream differentiation stages. During hESC differentiation, ECM and MMPs are secreted which remodels the exogenous ECM on the culture substrate (Brafman et al., 2013). PSCs cultured on substrates supplemented with ECM proteins did not significantly improve beta cell maturation over 1-2 weeks, perhaps due to the contribution of celldeposited ECM proteins. In self-organized PSC-derived beta cell clusters, cells deposit ECM which is largely composed of collagen IV, laminin, and fibronectin (Youngblood et al., 2019). This suggests guiding cell differentiation with ECM may not be a fruitful strategy in $3 \mathrm{D}$ aggregates or over longer time scales but could be used to improve initial differentiation after seeding.

\section{Biomechanical Effects Soluble Factor-Based Modulation of Mechanotransducive Machinery}

More recent differentiation strategies can achieve dynamic glycemic control in PSC-derived cells has been achieved by aggregating insulin-positive clusters (Nair et al., 2019; VelazcoCruz et al., 2019), maturation through transplantation (Motté et al., 2014; Robert et al., 2018), or by timed activation of TGF$\beta$ signaling in aggregates (Velazco-Cruz et al., 2019). All these promising protocols present a combination of biochemical and biomechanical stimuli applied to the PSC-derived pancreatic progenitor cells. Mechanotransduction occurs via complex machinery within a cell that involves interplay between ECM connections (e.g., integrins, adherens), cytoskeletal organization, and the nuclear envelope (Eyckmans et al., 2011). Rather than mimic soluble factors present in vivo, a recent successful strategy has been to target specific mechanotransductionassociated pathways during directed differentiation to promote pancreatic differentiation and thus improve the capacity to produce insulin-secreting cells. Such factors include H1152 (a ROCK II inhibitor) (Ghazizadeh et al., 2017), verteporfin (Rosado-Olivieri et al., 2019), and latrunculin A (disrupts microfilament organization) (Hogrebe et al., 2020). Nuclear activation of YAP, which affects the mechanosensitive Hippo pathway, is inversely correlated with expression of pancreatic and endocrine markers, PDX1 and NGN3 respectively (Mamidi et al., 2018). Timed inhibition of YAP with verteporfin enhances endocrine differentiation while depleting the pancreatic progenitor population which may have benefits for downstream transplantation (Rosado-Olivieri et al., 2019). Depolymerizing the actin cytoskeleton with latrunculin A allowed endocrine differentiation that was previously not possible in $2 \mathrm{D}$ adherent cultures, perhaps suggesting that mechanosensing via the cytoskeleton is important in this process (Hogrebe et al., 2020). Altogether, this suggests that components of the in vivo cellular microenvironment are crucial for differentiation 
protocols and investigating how cells interact the surrounding extracellular matrix may be important in improving pancreatic differentiation protocols.

\section{Biomechanical Cell Interactions}

Cells interact with ECM proteins by binding with integrin receptors spanning across the cell membrane. These receptors can then activate downstream integrin-related signaling pathways that alter cell function and bias cell specification. In pancreas development, integrin-ECM signaling regulates collective cell migration and function (Rosenberg et al., 1999; Hammar et al., 2004; Shih et al., 2016). When pluripotent, hESCs express integrin domains $\alpha 6$ and $\beta 1$ for laminin binding but this is downregulated after definitive endoderm differentiation (Wong et al., 2010). Differentiation toward definitive endoderm lineage with fibronectin and vitronectin is regulated by increased expression of integrin receptors $\alpha 5$, $\alpha \mathrm{V}, \beta 5$ (Wong et al., 2010; Brafman et al., 2013). Further downstream, ECM-integrin $\alpha 5$ signaling associated with fibronectin binding promoted differentiation to pancreatic duct while disruption of this pathway enhanced endocrine differentiation (Mamidi et al., 2018). Although not yet studied in the context of mechanosensing for pancreatic differentiation, other surface receptors, such as stretch-activated ion channels (Liu et al., 2015; Nourse and Pathak, 2017), growth factor receptors (Tschumperlin et al., 2004), and cadherins (Ganz et al., 2006; Mui et al., 2016) could also play a role in guiding differentiation.

The surrounding ECM matrix also propagates stress (Wang H. et al., 2014) which allows cells to sense biomechanical cues through ECM-bound integrins (D’Angelo et al., 2011). Cells can also apply traction forces on the ECM through their integrin connections. Cells with high spread area also generate higher tractions forces (Rape et al., 2011; Han et al., 2012). Thus, these biomechanical interactions with ECM proteins may guide pancreatic differentiation through cell-generated forces caused by changes in the actin cytoskeleton organization. Integrin signaling drives cell-generated traction forces which are required for endoderm specification (Taylor-Weiner et al., 2015). Pathway analysis of single hiPSC-derived pancreatic cells encapsulated in alginate further suggests that integrin-signaling is involved in the cells' ability to transduce mechanical confinement toward islet differentiation pathways (Legøy et al., 2020).

Cell morphology is guided by the ECM proteins of the culture substrate (Watt, 1986; Polte et al., 2004) which could affect differentiation by regulating gene expression through changes in endogenous tension (McBeath et al., 2004; Kilian et al., 2010; Lee et al., 2016). In differentiation of $\mathrm{NGN}^{+}$endocrine progenitors, fibronectin promotes high cell spread area while laminin-coated surfaces were associated with lower spreading (Mamidi et al., 2018). Aside from these biochemical signaling cues, cell behavior is dependent on the fibrous architecture and the apparent stiffness of the ECM, which both provide biomechanical cues to influence cell behavior. Therefore, it is important to try to decouple the specific ECM protein effects from the structural or mechanical stimuli provided by the ECM.

\section{Fluid Flow}

Pancreatic islets are highly vascularized tissues which is important for efficient oxygenation and rapid insulin response (Jansson and Hellerström, 1983; Carlsson et al., 1998). Microfluidics can resolve time-dependent secretion and metabolism of islets which would normally not be possible with conventional static cultures (Rocheleau et al., 2004; Wang et al., 2010; Nourmohammadzadeh et al., 2016; Walker et al., 2020). When cultured directly under high external flow rates, shear stress damages peripheral islet cells, reducing glucose-stimulated metabolism and calcium response (Shenkman et al., 2009; Sankar et al., 2011; Silva et al., 2013). However, blood flow (Wang et al., 2010) and islet culture in bioreactors (Minteer et al., 2014) also improves mass transfer to pancreatic islets (Wu et al., 2014), improving islet survival and function (Lock et al., 2011; Sankar et al., 2011) - particularly if the islets are protected from shear stress (Jun et al., 2019). Islets with endothelial cells cocultured under external flow have higher endothelial cell survival compared to static culture which may improve islet functionality and health ex vivo, perhaps by mediating regeneration of islet ECM within aggregates (Sankar et al., 2011; Jun et al., 2019). Culture with low flow rates permits paracrine signaling between neighboring islet hormone cells and the low shear rates may help microvilli maintenance, which was correlated to insulin secretion capabilities (Bendayan, 1992; Geron et al., 2015; Jun et al., 2019).

Signals from pancreatic vasculature are critical in specifying differentiation (Lammert et al., 2001) but the role of shear stress on differentiation is not well-understood. There are many reports of pancreatic differentiation within stirred bioreactors (Schulz et al., 2012; Pagliuca et al., 2014; Mihara et al., 2017; Yabe et al., 2019) however little has been done to characterize the effect of shear stress on pancreatic differentiation within these systems. The differentiation of embryoid bodies under external flow promoted expression of beta cell specific markers, such as NKX6.1 and INS, and improved glucose-stimulated insulin secretion sensitivity over static conditions (Tao et al., 2019). In the future it would be interesting to further investigate the biophysical effects of varying fluid flow rates on pancreatic differentiation and functionality.

\section{Substrate Stiffness}

Cells interact with aspects of the ECM, such as stiffness, by anchoring and pulling on the substrate. These signals are then transmitted through intracellular structures, such as the actin cytoskeleton, leading to downstream effects which alter cell fate decisions. Engler et al. (2006) showed that the differentiation of mesenchymal stem cells toward neurogenic, myogenic, and osteogenic lineages could be controlled by culturing cells on substrates of physiologically relevant in vivo stiffness. High stiffness environments reduce insulin expression of MIN6 cells confined in 3D polyacrylamide scaffolds (Nyitray et al., 2014). Therefore, the stiffness of the culture substrate is a key criterion in biomaterial and culture system selection when optimizing pancreatic differentiation protocols based on insulin-producing cell yield, purity and function (Table 1, Column 6).

One approach could be to mimic the stiffness of the pancreas which may better recapitulate in vivo cell function. The stiffness 
of the adult human pancreas lies within $1.4 \pm 2.1-4.4 \pm 5.1 \mathrm{kPa}$ (Sugimoto et al., 2014). In contrast, standard tissue culture polystyrene (TCPS) has a stiffness around $3 \mathrm{GPa}$ (Gilbert et al., 2010). Stiffness tunable hydrogels that can be functionalized with ECM proteins, such as polyacrylamide or hyaluronic acid gels, constitute interesting alternatives to polystyrene. Culture of pancreatic progenitors on substrates mimicking the stiffness of the pancreas is a promising strategy to promote differentiation relative to stiff polystyrene. Pancreatic differentiation of hESCs on relatively soft surfaces resulted in increased protein expression of PDX1, and gene expression of pancreatic endoderm markers, NKX2.2 and NKX6.1 (Narayanan et al., 2013; Maldonado et al., 2017). Similarly, hESCs encapsulated and differentiated in soft 3D alginate matrices were more viable, proliferative, and had increased PDX1 protein expression suggesting improved pancreatic commitment compared to stiffer gels (Richardson et al., 2016). Significant upregulation of pancreatic associated genes, such as PDX1, INS, and GLUT2, were observed during pancreatic differentiation of hESCs on soft hyaluronic acid hydrogels (Narayanan et al., 2013). hESC-derived beta cells cocultured with endothelial cells on Matrigel gels formed selfassembled networks of islet organoids with functional glucosestimulated insulin secretion while these organoids did not form on stiff TCPS coated with Matrigel or in suspension culture (Augsornworawat et al., 2019).

Changing stiffness in hydrogel systems could change the number of cell tethering sites due to increased crosslinking or ECM protein concentration, therefore proper controls are required (Trappmann et al., 2012). To decouple stiffness and substrate binding differences due to composition changes, substrates composed of pillars with controllable aspect ratio can be used to modulate the perceived stiffness while maintaining substrate composition. Nanopillars with a high aspect ratio are more flexible and perceived to be softer compared to those with a low aspect ratio, while maintaining substrate chemistry (Yang et al., 2011). Definitive endoderm differentiation from hESCs commitment is improved on high aspect ratio polycarbonate pillars and resulted in a more cluster-like morphology (Rasmussen et al., 2016b). Controlling cell morphology via substrate stiffness could be another approach to guide differentiation by altering internal cytoskeletal tension, which in turn impacts the compressive forces applied on the cell nucleus thus affecting transcriptional activation (McBeath et al., 2004; Driscoll et al., 2015) (Table 1, Column 7). Transdifferentiation of mouse dermal fibroblasts toward monohormonal pancreatic endocrine cells is improved on soft polyacrylamide gels $(1 \mathrm{kPa})$ and this was correlated with generation of large cell clusters, actin reorganization, and deactivation of YAP compared to culture on stiff substrates (Pennarossa et al., 2018).

During development, the embryo undergoes dynamic changes in ECM stiffness, architecture, and composition. Although optimizing substrates for one stage of differentiation could provide potential insight into developmental mechanics, this may decrease the fraction of pancreatic cells obtained downstream. Using soft, high aspect ratio pillars that promote definitive endoderm differentiation resulted in lower fraction of $\mathrm{PDX}^{+}$cells compared to flat, polycarbonate controls while the same substrates has decreased downstream pancreatic differentiation (Rasmussen et al., 2016b). Conversely, the formation of $\mathrm{PDX}^{+}$cells is promoted on soft electrospun fibers while the precursor mesendodermal cell differentiation is improved on stiffer substrates (Maldonado et al., 2017). Alginate encapsulation of single pancreatic progenitor cells at later stages of differentiation promoted an islet-like gene expression profile and increased the fraction of insulin-expressing cells compared to when PSCs were encapsulated at the beginning of differentiation, further suggesting stage specific optimization of these microenvironmental cues is required (Legøy et al., 2020). When comparing pancreatic differentiation results across multiple studies, the classification of "soft" versus "stiff" substrates in relation to the native microenvironment, the type of material, and the ECM used to facilitate cell adhesion must be considered (Table 1, Column 8).

\section{ECM Architecture/Topography}

The topography of the culture substrate can mediate cell clustering which is thought to promote pancreatic differentiation. The fibrous nature of native ECM can be mimicked using electrospun scaffolds. The ECM provides structural adhesive binding sites which influences the shape cells adopt on a substrate. Scaffolds, such as electrospun nanofibers, can be used to manipulate stem cell fate decisions by mimicking the topography and fibrous nature of native ECM proteins (Xin et al., 2007; Fujita et al., 2012; Kim et al., 2013; Luo et al., 2015). Human ESCs differentiated on $200 \mathrm{~nm}$ poly( $\varepsilon$-caprolactone) (PCL) fibers had higher expression of endodermal lineage genes such as SOX17 and FOXA2, compared to on larger fibers. Cells cultured on thin fibers adopted a clumped, rounded morphology while cells on fibers greater than $800 \mathrm{~nm}$ were more spread and anchored. Having a more clumped morphology could promote cell-cell interactions over cellsubstrate interactions which may bias differentiation (Ghanian et al., 2015). Microporous poly(lactide-co-glycolide) (PLG) and PEG scaffolds can promote aggregation into consistently sized clusters, which improves beta cell differentiation downstream (Youngblood et al., 2019). Culture on nanostructured zirconia substrates promotes clustering of dissociated human pancreatic islets, reduced actin cytoskeletal stress fiber formation, and increased the number of vinculin focal adhesions compared to flat substrates. These traits of zirconia substrates culture were correlated to improved islet survival, growth, and pancreatic differentiation (Galli et al., 2018). These studies suggest that careful selection of culture surface topography could be used to guide tissue organization, which may be a more economical, operator-free alternative to guiding cultures purely with biochemical cues or specialized aggregation techniques.

\section{CONCLUSION AND PERSPECTIVES}

Methods to produce functional beta cells from PSCs have advanced by leaps and bounds over the past two decades through advances such as directed differentiation which aimed to mimic the stages of pancreas development. In addition to soluble 


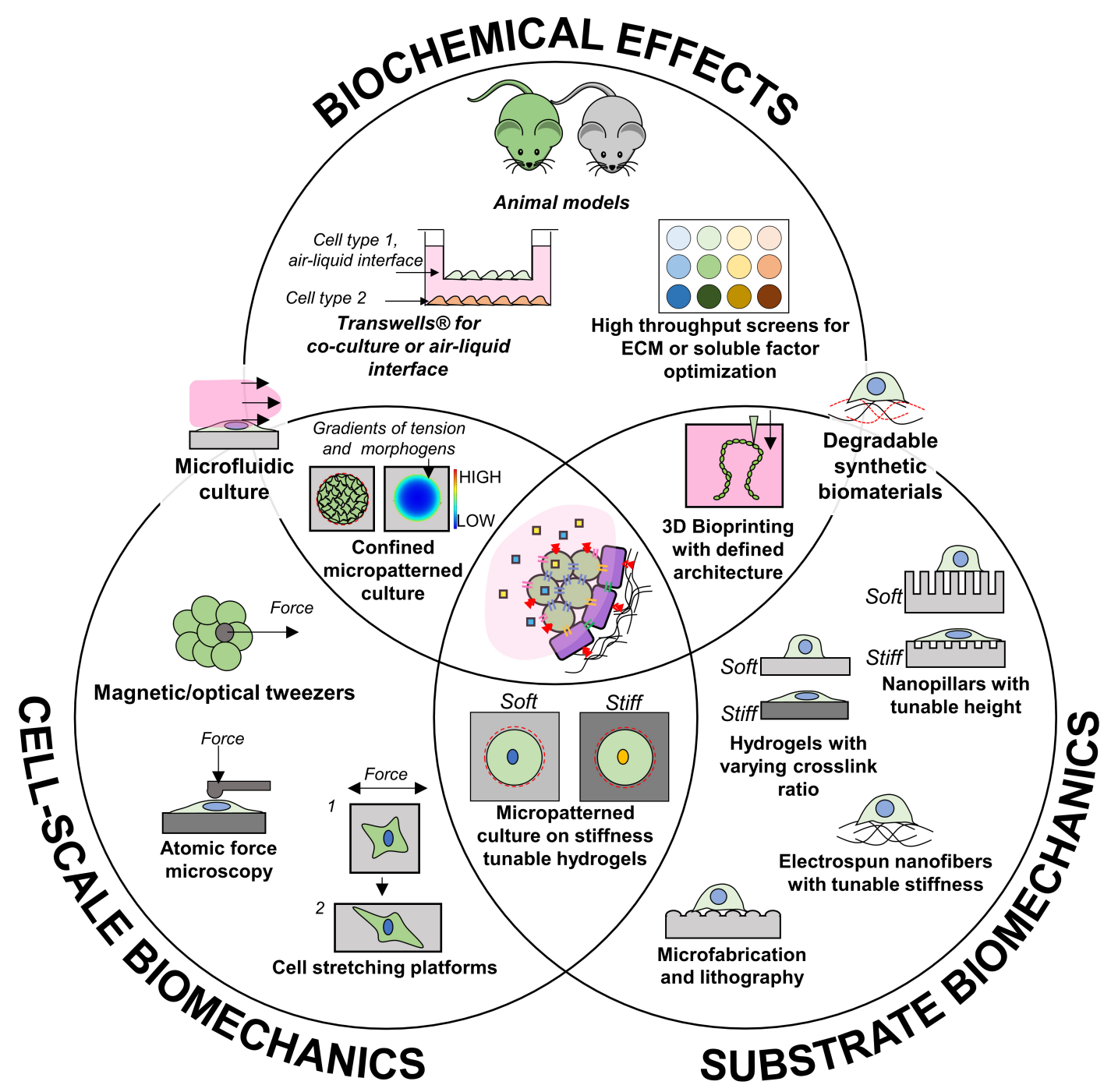

FIGURE 3 | Available technologies that could contribute to investigating independent aspects of pancreas development.

factors, the interactions between PSC-derived pancreatic cells with each other and with the ECM alter biomechanical stimuli which guide cell fate decision. Therefore, several aspects of the developing microenvironment must be taken into consideration when designing next-generation culture techniques and devices.

For one, understanding the roles of ECM proteins and structure in guiding different stages of differentiation may be crucial in accelerating early stages of differentiation or during transition points in culture. However, these biochemical and structural effects may only have short-term influences on differentiation and may diminish as differentiating pancreatic cells secrete their own native ECM. This speaks to the dynamic nature of the surrounding cellular microenvironment which may temporally vary in both biochemical composition and stiffness. Second, it is important to consider the material and perceived stiffness when interpreting results; a soft substrate in one paper could still be much stiffer than that of the native pancreas. In addition, appropriate design of substrates by controlling stiffness,
ECM functionalization, and nanotopography could promote aggregation and pancreatic differentiation. Cell aggregation is an integral part of many differentiation protocols and is clear to be important to obtaining functional beta cells, however, recent studies have shown aggregation may not be required for beta cell differentiation (Hogrebe et al., 2020). Therefore, investigating the functional or phenotypic differences between PSC-derived cells from aggregation culture and 2D protocols, if any, will be important proceeding with scale-up.

Studying and controlling the complex set of factors which guide pancreas development using in vitro models is challenging - particularly since stimuli from soluble factors, cell-cell interactions, and cell-ECM interactions are both interrelated and time-dependent. The progression of pancreatic differentiation will likely be dependent on gaining a fundamental understanding of development and then translating this knowledge to scalable technologies. For one, the dynamic nature of maturing cells changing the surrounding microenvironment, 
and the subsequent effect on differentiation is not wellunderstood. Complex in silico models and improved culture systems may be required to tease apart the many confounded effects of the dynamic cellular microenvironment. Previously, mathematical models of the interactions between biomechanical stimuli and regulatory gene networks have been used to predict MSC (Peng et al., 2017) and pancreatic cell fate decisions (Zhou et al., 2011, 2016; de Back et al., 2013; Wang et al., 2020). Novel in silico models which deal with cell generated forces in aggregate culture (Lee et al., 2019) while varying stiffness or cell organization over time could help us understand how mechanotransduction changes throughout a differentiating aggregate. As we move to more complex aggregates and culture systems, in silico models of biomechanics could shed light onto correlations between cell differentiation and varying substrate parameters. It is still not well-understood why stem cell-derived beta-like cell co-cultures with endothelial cells (Augsornworawat et al., 2019) have not been able to surpass protocols without coculture (Nair et al., 2019; Velazco-Cruz et al., 2019; Hogrebe et al., 2020). The presence of flow during culture might be required to recapitulate the effects of endothelial cells on islet development since hemodynamic stimuli have profound impact on endothelial cell function including their secretome (Berthiaume and Frangos, 1995; Burghoff and Schrader, 2011; Wang et al., 2013). In addition, mimicking vascular flow through organized endothelial cell-islet co-cultures could better mimic in vivo stimulation, and better reproduce nutrient gradients throughout the aggregates.

To address these questions, some technologies that could be used to specifically identify the effect of these factors are highlighted in Figure 3 but the state of the art is currently limited in the ability to emulate the temporal changes that occur during development. Once each independent effect is better understood, dynamic culture systems which leverage cell-cell interactions and timed biomechanical cues alongside soluble factor timing could be key for optimal production of functional beta cells. Future in vitro models implementing smart materials with dynamically tunable biomechanical properties could give insight to how the changing microenvironment could affect development. For example, synthetic scaffolds with defined ECM functionalization and degradation characteristics would allow for precise control of biochemical, topographical, and stiffness cues presented to differentiating cells. Such a technology could accelerate lengthy differentiation protocols and promote cell morphologies which allow for optimal beta cell organization. Alternatively, novel models which mimic dynamic shape changes in tissue morphogenesis (via novel 4D biomaterials) or stiffness (MMPmediated degradation or UV-based) could better accommodate

\section{REFERENCES}

Aisenbrey, E. A., and Murphy, W. L. (2020). Synthetic alternatives to Matrigel. Nat. Rev. Mater. 5, 539-551. doi: 10.1038/s41578-020-0199-8

Alberti, K., Davey, R. E., Onishi, K., George, S., Salchert, K., Seib, F. P., et al. (2008). Functional immobilization of signaling proteins enables control of stem cell fate. Nat. Methods 5, 645-650. doi: 10.1038/nmeth.1222

Amer, L. D., Holtzinger, A., Keller, G., Mahoney, M. J., and Bryant, S. J. (2015). Enzymatically degradable poly(ethylene glycol) hydrogels for the 3D culture the constantly changing requirements for beta cell differentiation. Finally, as our knowledge progresses, increasingly complex coculture systems involving defined compositions of PSC-derived endothelial, islet endocrine cells, and other cells present during development, may be the route to a functional cell source for islet transplantation.

Overall, better understanding the mechanobiology of pancreas development could lead to new strategies to more efficiently produce functional glucose-responsive, insulin-secreting cells for cell therapies. Interdisciplinary approaches combining advances in materials science and developmental biology could accelerate the development and scale up of culture systems tailored for diabetes cell therapy.

\section{AUTHOR CONTRIBUTIONS}

RT conducted the literature search and drafted the manuscript in consultation with $\mathrm{CM}$ and $\mathrm{CH}$. All authors contributed to writing the final manuscript.

\section{FUNDING}

The authors received funding from Canada's National Sciences and Engineering Research Council (NSERC; PGS-D award for RT, RGPIN-2015-05512 to CM, and RGPIN-2015-05877 to $\mathrm{CH}$ ) and the New Frontiers in Research Fund (NFRFE2018-01546, CH) which supported this work. This work was undertaken, in part, thanks to funding from the Canada Research Chairs program ( $\mathrm{CH}$ and $\mathrm{CM}$ ) and the 'Fueling Biotechnology Partnerships' program from the Canadian Stem Cell Network. We also thank JDRF and Diabète Québec for their support. RT and $\mathrm{CH}$ are members of the Quebec Network for Cell, Tissue and Gene Therapy - ThéCell (a thematic network supported by the Fonds de recherche du Québec-Santé), of the Québec Center for Advanced Materials (CQMF), of PROTEO (The Quebec Network for Research on Protein Function, Engineering, and Applications), of the Cardiometabolic Health, Diabetes and Obesity Research Network (CMDO), and of the Montreal Diabetes Research Center (MDRC). RT, CM, and $\mathrm{CH}$ are members of the McGill Regenerative Medicine Network.

\section{ACKNOWLEDGMENTS}

We thank Jonathan Brassard for editing this manuscript and insightful discussion.

and release of human embryonic stem cell derived pancreatic precursor cell aggregates. Acta Biomater. 22, 103-110. doi: 10.1016/j.actbio.2015. 04.013

Amit, M., Shariki, C., Margulets, V., and Itskovitz-Eldor, J. (2004). Feeder layerand serum-free culture of human embryonic stem cells1. Biol. Reprod. 70, 837-845. doi: 10.1095/biolreprod.103.021147

Antoni, D., Burckel, H., Josset, E., and Noel, G. (2015). Three-dimensional cell culture: a breakthrough in vivo. Int. J. Mol. Sci. 16, 5517-5527. doi: 10.3390/ ijms 16035517 
Arous, C., and Wehrle-Haller, B. (2017). Role and impact of the extracellular matrix on integrin-mediated pancreatic $\beta$-cell functions. Biol. Cell 109, 223-237. doi: 10.1111/boc.201600076

Assady, S., Maor, G., Amit, M., Itskovitz-Eldor, J., Skorecki, K. L., and Tzukerman, M. (2001). Insulin production by human embryonic stem cells. Diabetes Metab. Res. Rev. 50, 1691-1697. doi: 10.2337/diabetes.50.8.1691

Augsornworawat, P., Velazco-Cruz, L., Song, J., and Millman, J. R. (2019). A hydrogel platform for in vitro three dimensional assembly of human stem cell-derived islet cells and endothelial cells. Acta Biomater. 97, 272-280. doi: 10.1016/j.actbio.2019.08.031

Avgoustiniatos, E., and Colton, C. (1997). Effect of external oxygen mass transfer resistances on viability of immunoisolated tissue. Ann. N. Y. Acad. Sci. 831, 145-167. doi: 10.1111/j.1749-6632.1997.tb52192.x

Basson, M. A. (2012). Signaling in cell differentiation and morphogenesis. Cold Spring Harb. Perspect. Biol. 4:a008151. doi: 10.1101/cshperspect.a008151

Belair, D. G., Le, N. N., and Murphy, W. L. (2014). Design of growth factor sequestering biomaterials. Chem. Commun 50, 15651-15668. doi: 10.1039/ c4cc04317k

Bendayan, M. (1992). Association of secreted insulin with particular domains of the pancreatic B-cell plasma membrane: the actin-rich microvilli. J. Histochem. Cytochem. 40, 327-331. doi: 10.1177/40.3.1552173

Benitez, C. M., Goodyer, W. R., and Kim, S. K. (2012). Cold Spring Harb. Perspect. Biol. 4:a012401. doi: 10.1101/cshperspect.a012401

Berthiaume, F., and Frangos, J. A. (1995). "Flow effects on endothelial cell signal transduction, function, and mediator release," in Flow-Dependent Regulation of Vascular Function, eds J. A. Bevan, G. Kaley, and G. M. Rubanyi (New York, NY: Springer), 85-116. doi: 10.1007/978-1-4614-7527-9_5

Bi, H., Ye, K., and Jin, S. (2020). Proteomic analysis of decellularized pancreatic matrix identifies collagen $\mathrm{V}$ as a critical regulator for islet organogenesis from human pluripotent stem cells. Biomaterials 233:119673. doi: 10.1016/j. biomaterials.2019.119673

Bonnans, C., Chou, J., and Werb, Z. (2014). Remodelling the extracellular matrix in development and disease. Nat. Rev. Mol. Cell Biol. 15, 786-801. doi: 10.1038/ nrm3904

Brafman, D. A., Phung, C., Kumar, N., and Willert, K. (2013). Regulation of endodermal differentiation of human embryonic stem cells through integrinECM interactions. Cell Death Differ. 20, 369-381. doi: 10.1038/cdd.2012.138

Buchwald, P. (2009). FEM-based oxygen consumption and cell viability models for avascular pancreatic islets. Theor. Biol. Med. Model. 6:5. doi: 10.1186/17424682-6-5

Burghoff, S., and Schrader, J. (2011). Secretome of human endothelial cells under shear stress. J. Proteome Res. 10, 1160-1169. doi: 10.1021/pr100937a

Caicedo, A. (2013). Paracrine and autocrine interactions in the human islet: more than meets the eye. Semin. Cell Dev. Biol. 24, 11-21. doi: 10.1016/j.semcdb.2012. 09.007

Carlsson, P. O., Liss, P., Andersson, A., and Jansson, L. (1998). Measurements of oxygen tension in native and transplanted rat pancreatic islets. Diabetes Metab. Res. Rev 47, 1027-1032. doi: 10.2337/diabetes.47.7.1027

Chen, C. S. (2008). Mechanotransduction - a field pulling together? J. Cell Sci. 121, 3285-3292. doi: 10.1242/jcs. 023507

Chen, G., Gulbranson, D. R., Hou, Z., Bolin, J. M., Ruotti, V., Probasco, M. D., et al. (2011). Chemically defined conditions for human iPSC derivation and culture. Nat. Methods 8, 424-429. doi: 10.1038/nmeth.1593

Chowdhury, A., Dyachok, O., Tengholm, A., Sandler, S., and Bergsten, P. (2013). Functional differences between aggregated and dispersed insulin-producing cells. Diabetologia 56, 1557-1568. doi: 10.1007/s00125-013-2903-3

D'Amour, K. A., Agulnick, A. D., Eliazer, S., Kelly, O. G., Kroon, E., and Baetge, E. E. (2005). Efficient differentiation of human embryonic stem cells to definitive endoderm. Nat. Biotechnol. 23, 1534-1541. doi: 10.1038/ nbt1163

D’Amour, K. A., Bang, A. G., Eliazer, S., Kelly, O. G., Agulnick, A. D., Smart, N. G., et al. (2006). Production of pancreatic hormone-expressing endocrine cells from human embryonic stem cells. Nat. Biotechnol. 24, 1392-1401. doi: $10.1038 / \mathrm{nbt} 1259$

D’Angelo, F., Tiribuzi, R., Armentano, I., Kenny, J. M., Martino, S., and Orlacchio, A. (2011). Mechanotransduction: tuning stem cells fate. J. Funct. Biomater. 2, 67-87. doi: $10.3390 / \mathrm{jb} 2020067$
Dassaye, R., Naidoo, S., and Cerf, M. E. (2016). Transcription factor regulation of pancreatic organogenesis, differentiation and maturation. Islets 8, 13-34. doi: 10.1080/19382014.2015.1075687

Davis, J. C., Alves, T. C., Helman, A., Chen, J. C., Kenty, J. H., Cardone, R. L., et al. (2020). Glucose response by stem cell-derived $\beta$ cells in vitro is inhibited by a bottleneck in glycolysis. Cell Rep. 31:107623. doi: 10.1016/j.celrep.2020.107623

de Back, W., Zhou, J. X., and Brusch, L. (2013). On the role of lateral stabilization during early patterning in the pancreas. J. R. Soc. Interface 10:20120766. doi: 10.1098/rsif.2012.0766

Discher, D. E., Mooney, D. J., and Zandstra, P. W. (2009). Growth factors, matrices, and forces combine and control stem cells. Science 324, 1673-1677. doi: 10.1126/science. 1171643

Driscoll, T. P., Cosgrove, B. D., Heo, S.-J., Shurden, Z. E., and Mauck, R. L. (2015). Cytoskeletal to nuclear strain transfer regulates YAP signaling in mesenchymal stem cells. Biophys. J. 108, 2783-2793. doi: 10.1016/j.bpj.2015.05.010

Engler, A. J., Sen, S., Sweeney, H. L., and Discher, D. E. (2006). Matrix elasticity directs stem cell lineage specification. Cell 126, 677-689. doi: 10.1016/j.cell. 2006.06.044

Eyckmans, J., Boudou, T., Yu, X., and Chen, C. S. (2011). A hitchhiker's guide to mechanobiology. Dev. Cell 21, 35-47. doi: 10.1016/j.devcel.2011.06.015

Fang, B., Liu, Y., Zheng, D., Shan, S., Wang, C., Gao, Y., et al. (2019). The effects of mechanical stretch on the biological characteristics of human adipose-derived stem cells. J. Cell. Mol. Med. 23, 4244-4255. doi: 10.1111/jcmm.14314

Flaim, C. J., Chien, S., and Bhatia, S. N. (2005). An extracellular matrix microarray for probing cellular differentiation. Nat. Methods 2, 119-125. doi: 10.1038/ nmeth736

Foster, E. D., Bridges, N. D., Feurer, I. D., Eggerman, T. L., Hunsicker, L. G., and Alejandro, R. (2018). Improved health-related quality of life in a phase 3 islet transplantation trial in type 1 diabetes complicated by severe hypoglycemia. Diabetes Care 41, 1001-1008. doi: 10.2337/dc17-1779

Frank, V., Kaufmann, S., Wright, R., Horn, P., Yoshikawa, H. Y., Wuchter, P., et al. (2016). Frequent mechanical stress suppresses proliferation of mesenchymal stem cells from human bone marrow without loss of multipotency. Sci. Rep. 6:24264. doi: 10.1038/srep24264

Fujita, S., Shimizu, H., and Suye, S. (2012). Control of differentiation of human mesenchymal stem cells by altering the geometry of nanofibers. J. Nanotechnol. 2012:429890. doi: 10.1155/2012/429890

Gage, B. K., Webber, T. D., and Kieffer, T. J. (2013). Initial cell seeding density influences pancreatic endocrine development during in vitro differentiation of human embryonic stem cells. PLoS One 8:e82076. doi: 10.1371/journal.pone. 0082076

Galli, A., Maffioli, E., Sogne, E., Moretti, S., Di Cairano, E. S., Negri, A., et al. (2018). Cluster-assembled zirconia substrates promote long-term differentiation and functioning of human islets of Langerhans. Sci. Rep. 8:9979. doi: 10.1038/ s41598-018-28019-3

Ganz, A., Lambert, M., Saez, A., Silberzan, P., Buguin, A., Mège, R. M., et al. (2006). Traction forces exerted through N-cadherin contacts. Biol. Cell 98, 721-730. doi: 10.1042/BC20060039

Gao, B., Jing, C., Ng, K., Pingguan-Murphy, B., and Yang, Q. (2019). Fabrication of three-dimensional islet models by the geometry-controlled hanging-drop method. Acta Mech. Sin. 35, 329-337. doi: 10.1007/s10409-019-00856-z

Gattazzo, F., Urciuolo, A., and Bonaldo, P. (2014). Extracellular matrix: a dynamic microenvironment for stem cell niche. Biochim. Biophys. Acta 1840, 2506-2519. doi: 10.1016/j.bbagen.2014.01.010

George, N. M., Day, C. E., Boerner, B. P., Johnson, R. L., and Sarvetnick, N. E. (2012). Hippo signaling regulates pancreas development through inactivation of yap. Mol. Cell. Biol. 32, 5116-5128. doi: 10.1128/MCB.01034-12

Geron, E., Boura-Halfon, S., Schejter, E. D., and Shilo, B.-Z. (2015). The edges of pancreatic islet $\beta$ cells constitute adhesive and signaling microdomains. Cell Rep. 10, 317-325. doi: 10.1016/j.celrep.2014.12.031

Ghanian, M. H., Farzaneh, Z., Barzin, J., Zandi, M., Kazemi-Ashtiani, M., Alikhani, M., et al. (2015). Nanotopographical control of human embryonic stem cell differentiation into definitive endoderm. J. Biomed. Mater. Res. 103, 3539-3553. doi: 10.1002/jbm.a.35483

Ghazizadeh, Z., Kao, D.-I., Amin, S., Cook, B., Rao, S., Zhou, T., et al. (2017). ROCKII inhibition promotes the maturation of human pancreatic beta-like cells. Nat. Commun. 8:298. doi: 10.1038/s41467-017-00129-y 
Gilbert, P. M., Havenstrite, K. L., Magnusson, K. E. G., Sacco, A., Leonardi, N. A., Kraft, P., et al. (2010). Substrate elasticity regulates skeletal muscle stem cell self-renewal in culture. Science 329, 1078-1081. doi: 10.1126/science.11 91035

Glieberman, A. L., Pope, B. D., Zimmerman, J. F., Liu, Q., Ferrier, J. P., Kenty, J. H. R., et al. (2019). Synchronized stimulation and continuous insulin sensing in a microfluidic human Islet on a Chip designed for scalable manufacturing. Lab Chip 19, 2993-3010. doi: 10.1039/C9LC00253G

Goh, S.-K., Bertera, S., Olsen, P., Candiello, J., Halfter, W., Uechi, G., et al. (2013). Perfusion-decellularized pancreas as a natural 3D scaffold for pancreatic tissue and whole organ engineering. Biomaterials 34, 6760-6772. doi: 10.1016/ j.biomaterials.2013.05.066

Greggio, C., De Franceschi, F., Figueiredo-Larsen, M., Gobaa, S., Ranga, A., Semb, H., et al. (2013). Artificial three-dimensional niches deconstruct pancreas development in vitro. Development 140, 4452-4462. doi: 10.1242/dev.096628

Guilak, F., Cohen, D. M., Estes, B. T., Gimble, J. M., Liedtke, W., and Chen, C. S. (2009). Control of stem cell fate by physical interactions with the extracellular matrix. Cell Stem Cell 5, 17-26. doi: 10.1016/j.stem.2009.06.016

Guruswamy Damodaran, R., and Vermette, P. (2018). Decellularized pancreas as a native extracellular matrix scaffold for pancreatic islet seeding and culture. J. Tissue Eng. Regen. Med. 12, 1230-1237. doi: 10.1002/term.2655

Hakim, F., Kaitsuka, T., Raeed, J. M., Wei, F.-Y., Shiraki, N., Akagi, T., et al. (2014). High oxygen condition facilitates the differentiation of mouse and human pluripotent stem cells into pancreatic progenitors and insulin-producing cells. J. Biol. Chem. 289, 9623-9638. doi: 10.1074/jbc.M113.524363

Hammar, E., Parnaud, G., Bosco, D., Perriraz, N., Maedler, K., Donath, M., et al. (2004). Extracellular matrix protects pancreatic $\beta$-cells against apoptosis. Diabetes 53, 2034-2041. doi: 10.2337/diabetes.53.8.2034

Han, S. J., Bielawski, K. S., Ting, L. H., Rodriguez, M. L., and Sniadecki, N. J. (2012). Decoupling substrate stiffness, spread area, and micropost density: a close spatial relationship between traction forces and focal adhesions. Biophys. J. 103, 640-648. doi: 10.1016/j.bpj.2012.07.023

Hansson, M., Tonning, A., Frandsen, U., Petri, A., Rajagopal, J., Englund, M. C. O., et al. (2004). Artifactual insulin release from differentiated embryonic stem cells. Diabetes Metab. Res. Rev. 53, 2603-2609. doi: 10.2337/diabetes.53.10.2603

Hardikar, A. A., Marcus-Samuels, B., Geras-Raaka, E., Raaka, B. M., and Gershengorn, M. C. (2003). Human pancreatic precursor cells secrete FGF2 to stimulate clustering into hormone-expressing islet-like cell aggregates. Proc. Natl. Acad. Sci. U.S.A. 100, 7117-7122. doi: 10.1073/pnas. 1232230100

Hashemitabar, M., and Heidari, E. (2019). Redefining the signaling pathways from pluripotency to pancreas development: in vitro $\beta$-cell differentiation. J. Cell. Physiol. 234, 7811-7827. doi: 10.1002/jcp.27736

Heinis, M., Simon, M.-T., Ilc, K., Mazure, N. M., Pouysségur, J., Scharfmann, R., et al. (2010). Oxygen tension regulates pancreatic $\beta$-cell differentiation through hypoxia-inducible factor $1 \alpha$. Diabetes Metab. Res. Rev. 59, 662-669. doi: $10.2337 / \mathrm{db} 09-0891$

Heisenberg, C.-P., and Bellaïche, Y. (2013). Forces in tissue morphogenesis and patterning. Cell 153, 948-962. doi: 10.1016/j.cell.2013.05.008

Hellman, B. (1959). Actual distribution of the number and volume of the islets of langerhans in different size classes in non-diabetic humans of varying ages. Nature 184, 1498-1499. doi: 10.1038/1841498a0

Hilderink, J., Spijker, S., Carlotti, F., Lange, L., Engelse, M., van Blitterswijk, C., et al. (2015). Controlled aggregation of primary human pancreatic islet cells leads to glucose-responsive pseudoislets comparable to native islets. J. Cell. Mol. Med. 19, 1836-1846. doi: 10.1111/jcmm.12555

Hoesli, C. A., Raghuram, K., Kiang, R. L. J., Mocinecová, D., Hu, X., Johnson, J. D., et al. (2011). Pancreatic cell immobilization in alginate beads produced by emulsion and internal gelation. Biotechnol. Bioeng. 108, 424-434. doi: 10. 1002/bit.22959

Hogrebe, N. J., Augsornworawat, P., Maxwell, K. G., Velazco-Cruz, L., and Millman, J. R. (2020). Targeting the cytoskeleton to direct pancreatic differentiation of human pluripotent stem cells. Nat. Biotechnol. 38, 460-470. doi: 10.1038/s41587-020-0430-6

Hohwieler, M., Illing, A., Hermann, P. C., Mayer, T., Stockmann, M., Perkhofer, L., et al. (2017). Human pluripotent stem cell-derived acinar/ductal organoids generate human pancreas upon orthotopic transplantation and allow disease modelling. Gut 66, 473-486. doi: 10.1136/gutjnl-2016-312423
Hrvatin, S., O’Donnell, C. W., Deng, F., Millman, J. R., Pagliuca, F. W., DiIorio, P., et al. (2014). Differentiated human stem cells resemble fetal, not adult, $\beta$ cells. Proc. Natl. Acad. Sci. U.S.A. 111, 3038-3043. doi: 10.1073/pnas.1400709111

Ionescu-Tirgoviste, C., Gagniuc, P. A., Gubceac, E., Mardare, L., Popescu, I., Dima, S., et al. (2015). A 3D map of the islet routes throughout the healthy human pancreas. Sci. Rep. 5:14634.

Jansson, L., and Hellerström, C. (1983). Stimulation by glucose of the blood flow to the pancreatic islets of the rat. Diabetologia 25, 45-50. doi: 10.1007/BF00251896

Jaramillo, M., Mathew, S., Mamiya, H., Goh, S. K., and Banerjee, I. (2015) Endothelial cells mediate islet-specific maturation of human embryonic stem cell-derived pancreatic progenitor cells. Tissue Eng. Part A 21, 14-25. doi: 10. 1089/ten.TEA.2014.0013

Jennings, R. E., Berry, A. A., Strutt, J. P., Gerrard, D. T., and Hanley, N. A. (2015). Human pancreas development. Development 142, 3126-3137. doi: 10.1242/dev. 120063

Jin, L., Feng, T., Shih, H. P., Zerda, R., Luo, A., Hsu, J., et al. (2013). Colonyforming cells in the adult mouse pancreas are expandable in Matrigel and form endocrine/acinar colonies in laminin hydrogel. Proc. Natl. Acad. Sci. U.S.A. 110, 3907-3912. doi: 10.1073/pnas.1301889110

Jin, L., Gao, D., Feng, T., Tremblay, J. R., Ghazalli, N., Luo, A., et al. (2016). Cells with surface expression of CD133highCD71low are enriched for tripotent colony-forming progenitor cells in the adult murine pancreas. Stem Cell Res. 16, 40-53. doi: 10.1016/j.scr.2015.11.015

Jun, Y., Lee, J., Choi, S., Yang, J. H., Sander, M., Chung, S., et al. (2019). In vivomimicking microfluidic perfusion culture of pancreatic islet spheroids. Sci. Adv. 5:eaax4520. doi: 10.1126/sciadv.aax4520

Kelly, C., McClenaghan, N. H., and Flatt, P. R. (2011). Role of islet structure and cellular interactions in the control of insulin secretion. Islets 3, 41-47. doi: 10.4161/isl.3.2.14805

Kilian, K. A., Bugarija, B., Lahn, B. T., and Mrksich, M. (2010). Geometric cues for directing the differentiation of mesenchymal stem cells. Proc. Natl. Acad. Sci. U.S.A. 107, 4872-4877. doi: 10.1073/pnas.0903269107

Kim, J., Kim, H. N., Lim, K.-T., Kim, Y., Seonwoo, H., Park, S. H., et al. (2013). Designing nanotopographical density of extracellular matrix for controlled morphology and function of human mesenchymal stem cells. Sci. Rep. 3:3552. doi: $10.1038 /$ srep03552

Kim, J., Shim, I. K., Hwang, D. G., Lee, Y. N., Kim, M., Kim, H., et al. (2019). 3D cell printing of islet-laden pancreatic tissue-derived extracellular matrix bioink constructs for enhancing pancreatic functions. J. Mater. Chem. B 7, 1773-1781. doi: $10.1039 / \mathrm{C} 8 \mathrm{~TB} 02787 \mathrm{~K}$

Komatsu, H., Cook, C., Wang, C.-H., Medrano, L., Lin, H., Kandeel, F., et al. (2017). Oxygen environment and islet size are the primary limiting factors of isolated pancreatic islet survival. PLoS One 12:e183780. doi: 10.1371/journal. pone. 0183780

Kroon, E. (2008). Pancreatic endoderm derived from human embryonic stem cells generates glucose-responsive insulin-secreting cells in vivo. Nat. Biotechnol. 26, 443-452. doi: 10.1038/nbt1393

LaBarge, M. A., Nelson, C. M., Villadsen, R., Fridriksdottir, A., Ruth, J. R., Stampfer, M. R., et al. (2009). Human mammary progenitor cell fate decisions are products of interactions with combinatorial microenvironments. Integr. Biol. 1, 70-79. doi: 10.1039/B816472J

Lammert, E., Cleaver, O., and Melton, D. (2001). Induction of pancreatic differentiation by signals from blood vessels. Science 294, 564-567. doi: 10.1126/ science. 1064344

Lebreton, F., Lavallard, V., Bellofatto, K., Bonnet, R., Wassmer, C. H., Perez, L., et al. (2019). Insulin-producing organoids engineered from islet and amniotic epithelial cells to treat diabetes. Nat. Commun. 10:4491. doi: 10.1038/s41467019-12472-3

Lecomte, M.-J., Pechberty, S., Machado, C., Da Barroca, S., Ravassard, P., Scharfmann, R., et al. (2016). Aggregation of engineered human $\beta$-Cells into Pseudoislets: insulin secretion and gene expression profile in normoxic and hypoxic milieu. Cell Med. 8, 99-112. doi: 10.3727/215517916X692843

Lee, J., Abdeen, A. A., Wycislo, K. L., Fan, T. M., and Kilian, K. A. (2016). Interfacial geometry dictates cancer cell tumorigenicity. Nat. Mater. 15, 856-862. doi: $10.1038 /$ nmat 4610

Lee, W., Kalashnikov, N., Mok, S., Halaoui, R., Kuzmin, E., Putnam, A. J., et al. (2019). Dispersible hydrogel force sensors reveal patterns of solid mechanical 
stress in multicellular spheroid cultures. Nat. Commun. 10:144. doi: 10.1038/ s41467-018-07967-4

Legøy, T. A., Vethe, H., Abadpour, S., Strand, B. L., Scholz, H., Paulo, J. A., et al. (2020). Encapsulation boosts islet-cell signature in differentiating human induced pluripotent stem cells via integrin signalling. Sci. Rep. 10:414. doi: 10.1038/s41598-019-57305-x

Li, X. Y., Wu, S. Y., and Leung, P. S. (2019). human fetal bone marrowderived mesenchymal stem cells promote the proliferation and differentiation of pancreatic progenitor cells and the engraftment function of islet-like cell clusters. Int. J. Mol. Sci. 20:4083. doi: 10.3390/ijms20174083

Liu, Y.-S., Liu, Y.-A., Huang, C.-J., Yen, M.-H., Tseng, C.-T., Chien, S., et al. (2015). Mechanosensitive TRPM7 mediates shear stress and modulates osteogenic differentiation of mesenchymal stromal cells through Osterix pathway. Sci. Rep. 5:16522. doi: 10.1038/srep16522

Llacua, A., de Haan, B. J., Smink, S. A., and de Vos, P. (2016). Extracellular matrix components supporting human islet function in alginate-based immunoprotective microcapsules for treatment of diabetes. J. Biomed. Mater. Res. Part A 104, 1788-1796. doi: 10.1002/jbm.a.35706

Lock, L. T., Laychock, S. G., and Tzanakakis, E. S. (2011). Pseudoislets in stirredsuspension culture exhibit enhanced cell survival, propagation and insulin secretion. J. Biotechnol. 151, 278-286. doi: 10.1016/j.jbiotec.2010.12.015

Ludwig, B., Rotem, A., Schmid, J., Weir, G. C., Colton, C. K., Brendel, M. D., et al. (2012). Improvement of islet function in a bioartificial pancreas by enhanced oxygen supply and growth hormone releasing hormone agonist. Proc. Natl. Acad. Sci. U.S.A. 109, 5022. doi: 10.1073/pnas. 1201868109

Ludwig, T. E., Levenstein, M. E., Jones, J. M., Berggren, W. T., Mitchen, E. R., Frane, J. L., et al. (2006). Derivation of human embryonic stem cells in defined conditions. Nat. Biotechnol. 24, 185-187. doi: 10.1038/nbt1177

Luo, Y., Shen, H., Fang, Y., Cao, Y., Huang, J., Zhang, M., et al. (2015). Enhanced proliferation and osteogenic differentiation of mesenchymal stem cells on graphene oxide-incorporated electrospun poly(lactic-co-glycolic acid) nanofibrous mats. ACS Appl. Mater. Interfaces 7, 6331-6339. doi: 10.1021/ acsami.5b00862

Maldonado, M. (2015). The effects of electrospun substrate-mediated cell colony morphology on the self-renewal of human induced pluripotent stem cells. Biomaterials 50, 10-19. doi: 10.1016/j.biomaterials.2015.01.037

Maldonado, M., Luu, R. J., Ico, G., Ospina, A., Myung, D., Shih, H. P., et al. (2017). Lineage- and developmental stage-specific mechanomodulation of induced pluripotent stem cell differentiation. Stem Cell Res. Ther. 8:216. doi: 10.1186/ s13287-017-0667-2

Malta, D. F. B., Reticker-Flynn, N. E., da Silva, C. L., Cabral, J. M. S., Fleming, H. E., Zaret, K. S., et al. (2016). Extracellular matrix microarrays to study inductive signaling for endoderm specification. Acta Biomater. 34, 30-40. doi: 10.1016/j.actbio.2016.02.014

Mamidi, A., Prawiro, C., Seymour, P. A., de Lichtenberg, K. H., Jackson, A., Serup, P., et al. (2018). Mechanosignalling via integrins directs fate decisions of pancreatic progenitors. Nature 564, 114-118. doi: 10.1038/s41586-018-0762-2

Martino, F., Perestrelo, A. R., Vinarský, V., Pagliari, S., and Forte, G. (2018). Cellular mechanotransduction: from tension to function. Front. Physiol. 9:824. doi: 10.3389/fphys.2018.00824

Mason, M. N., and Mahoney, M. J. (2008). Selective $\beta$-cell differentiation of dissociated embryonic pancreatic precursor cells cultured in synthetic polyethylene glycol hydrogels. Tissue Eng. Part A 15, 1343-1352. doi: 10.1089/ ten.tea.2008.0290

McBeath, R., Pirone, D. M., Nelson, C. M., Bhadriraju, K., and Chen, C. S. (2004). Cell shape, cytoskeletal tension, and RhoA regulate stem cell lineage commitment. Dev. Cell 6, 483-495. doi: 10.1016/S1534-5807(04)00075-9

Medina, J. D., Alexander, M., Hunckler, M. D., Fernández-Yagüe, M. A., Coronel, M. M., Smink, A. M., et al. (2020). Functionalization of alginate with extracellular matrix peptides enhances viability and function of encapsulated porcine islets. Adv. Healthc. Mater. 9:2000102. doi: 10.1002/adhm.202000102

Mihara, Y., Matsuura, K., Sakamoto, Y., Okano, T., Kokudo, N., and Shimizu, T. (2017). Production of pancreatic progenitor cells from human induced pluripotent stem cells using a three-dimensional suspension bioreactor system. J. Tissue Eng. Regen. Med. 11, 3193-3201. doi: 10.1002/term.2228

Millman, J. R., Xie, C., Van Dervort, A., Gürtler, M., Pagliuca, F. W., and Melton, D. A. (2016). Generation of stem cell-derived $\beta$-cells from patients with type 1 diabetes. Nat. Commun. 7:11463.
Minteer, D. M., Gerlach, J. C., and Marra, K. G. (2014). Bioreactors addressing diabetes mellitus. J. Diabetes Sci. Technol. 8, 1227-1232. doi: 10.1177/ 1932296814548215

Moraes, C., Sun, Y., and Simmons, C. A. (2011). (Micro)managing the mechanical microenvironment. Integr. Biol. 3, 959-971. doi: 10.1039/clib00056j

Motté, E., Szepessy, E., Suenens, K., Stangé, G., Bomans, M., Jacobs-TulleneersThevissen, D., et al. (2014). Composition and function of macroencapsulated human embryonic stem cell-derived implants: comparison with clinical human islet cell grafts. Am. J. Physiol. Endocrinol. Metab. 307, E838-E846. doi: 10.1152/ ajpendo.00219.2014

Mui, K. L., Chen, C. S., and Assoian, R. K. (2016). The mechanical regulation of integrin-cadherin crosstalk organizes cells, signaling and forces. J. Cell Sci. 129, 1093-1100. doi: 10.1242/jcs. 183699

Nair, G. G., Liu, J. S., Russ, H. A., Tran, S., Saxton, M. S., Chen, R., et al. (2019). Recapitulating endocrine cell clustering in culture promotes maturation of human stem-cell-derived $\beta$ cells. Nat. Cell Biol. 21, 263-274. doi: 10.1038/ s41556-018-0271-4

Nakayama, K. H., Hou, L., and Huang, N. F. (2014). Role of extracellular matrix signaling cues in modulating cell fate commitment for cardiovascular tissue engineering. Adv. Healthc. Mater. 3, 628-641. doi: 10.1002/adhm.201300620

Narayanan, K., Lim, V. Y., Shen, J., Tan, Z. W., Rajendran, D., Luo, S.-C., et al. (2013). Extracellular matrix-mediated differentiation of human embryonic stem cells: differentiation to insulin-secreting beta cells. Tissue Eng. Part A 20, 424-433. doi: 10.1089/ten.tea.2013.0257

Naujok, O., Francini, F., Picton, S., Bailey, C. J., Lenzen, S., and Jörns, A. (2009). Changes in gene expression and morphology of mouse embryonic stem cells on differentiation into insulin-producing cells in vitro and in vivo. Diabetes Metab. Res. Rev. 25, 464-476. doi: 10.1002/dmrr.965

Negi, S., Jetha, A., Aikin, R., Hasilo, C., Sladek, R., and Paraskevas, S. (2012). Analysis of beta-cell gene expression reveals inflammatory signaling and evidence of dedifferentiation following human islet isolation and culture. PLoS One 7:e30415. doi: 10.1371/journal.pone.0030415

Nostro, M. C., Sarangi, F., Yang, C., Holland, A., Elefanty, A. G., Stanley, E. G., et al. (2015). Efficient generation of NKX6-1(+) pancreatic progenitors from multiple human pluripotent stem cell lines. Stem Cell Rep. 4, 591-604. doi: 10.1016/j.stemcr.2015.02.017

Nourmohammadzadeh, M., Xing, Y., Lee, J. W., Bochenek, M. A., Mendoza-Elias, J. E., McGarrigle, J. J., et al. (2016). A microfluidic array for real-time livecell imaging of human and rodent pancreatic islets. Lab Chip 16, 1466-1472. doi: $10.1039 / \mathrm{c} 5 \mathrm{lc} 01173 \mathrm{f}$

Nourse, J. L., and Pathak, M. M. (2017). How cells channel their stress: interplay between Piezol and the cytoskeleton. Semin. Cell Dev. Biol. 71, 3-12. doi: 10.1016/j.semcdb.2017.06.018

Nyitray, C. E., Chavez, M. G., and Desai, T. A. (2014). Compliant 3D microenvironment improves $\beta$-cell cluster insulin expression through mechanosensing and $\beta$-catenin signaling. Tissue Eng. Part A 20, 1888-1895. doi: 10.1089/ten.TEA.2013.0692

Offield, M. F., Jetton, T. L., Labosky, P. A., Ray, M., Stein, R. W., Magnuson, M. A., et al. (1996). PDX-1 is required for pancreatic outgrowth and differentiation of the Rostral duodenum. Development 122, 983-995.

Osafune, K., Caron, L., Borowiak, M., Martinez, R. J., Fitz-Gerald, C. S., Sato, Y., et al. (2008). Marked differences in differentiation propensity among human embryonic stem cell lines. Nat. Biotechnol. 26, 313-315. doi: 10.1038/nbt1383

Pagliuca, F. W., Millman, J. R., Gürtler, M., Segel, M., Van Dervort, A., Ryu, J. H., et al. (2014). Generation of functional human pancreatic $\beta$ cells in vitro. Cell 159, 428-439. doi: 10.1016/j.cell.2014.09.040

Pan, F. C., and Wright, C. (2011). Pancreas organogenesis: from bud to plexus to gland. Dev. Dyn. 240, 530-565. doi: 10.1002/dvdy.22584

Paraskevas, S., Maysinger, D., Wang, R., Duguid, W. P., and Rosenberg, L. (2000). Cell loss in isolated human islets occurs by apoptosis. Pancreas 20, 270-276. doi: 10.1097/00006676-200004000-00008

Pedersen, M. G., Bertram, R., and Sherman, A. (2005). Intra- and inter-islet synchronization of metabolically driven insulin secretion. Biophys. J. 89, 107119. doi: 10.1529/biophysj.104.055681

Peng, T., Liu, L., MacLean, A. L., Wong, C. W., Zhao, W., and Nie, Q. (2017). A mathematical model of mechanotransduction reveals how mechanical memory regulates mesenchymal stem cell fate decisions. BMC Syst. Biol. 11:55. doi: 10.1186/s12918-017-0429-x 
Pennarossa, G., Santoro, R., Manzoni, E. F. M., Pesce, M., Gandolfi, F., and Brevini, T. A. L. (2018). Epigenetic erasing and pancreatic differentiation of dermal fibroblasts into insulin-producing cells are boosted by the use of low-stiffness substrate. Stem Cell Rev. Rep. 14, 398-411. doi: 10.1007/s12015-017-9799-0

Piccolo, S., Dupont, S., and Cordenonsi, M. (2014). The Biology of YAP/TAZ: hippo signaling and beyond. Physiol. Rev. 94, 1287-1312. doi: 10.1152/physrev.00005. 2014

Polte, T. R., Eichler, G. S., Wang, N., and Ingber, D. E. (2004). Extracellular matrix controls myosin light chain phosphorylation and cell contractility through modulation of cell shape and cytoskeletal prestress. Am. J. Physiol. Cell Physiol. 286, C518-C528. doi: 10.1152/ajpcell.00280.2003

Rajagopal, J., Anderson, W. J., Kume, S., Martinez, O. I., and Melton, D. A. (2003). Insulin staining of ES cell progeny from insulin uptake. Science 299:363. doi: $10.1126 /$ science. 1077838

Rape, A., Guo, W., and Wang, Y. (2011). The regulation of traction force in relation to cell shape and focal adhesions. Biomaterials 32, 2043-2051. doi: 10.1016/j.biomaterials.2010.11.044

Rasmussen, C. H., Petersen, D. R., Moeller, J. B., Hansson, M., and Dufva, M. (2016a). Collagen type I improves the differentiation of human embryonic stem cells towards definitive endoderm. PLoS One 10:e0145389. doi: 10.1371/journal. pone. 0145389

Rasmussen, C. H., Reynolds, P. M., Petersen, D. R., Hansson, M., McMeeking, R. M., Dufva, M., et al. (2016b). Enhanced differentiation of human embryonic stem cells toward definitive endoderm on ultrahigh aspect ratio nanopillars. Adv. Funct. Mater. 26, 815-823. doi: 10.1002/adfm.201504204

Rezania, A., Bruin, J. E., Arora, P., Rubin, A., Batushansky, I., Asadi, A., et al. (2014). Reversal of diabetes with insulin-producing cells derived in vitro from human pluripotent stem cells. Nat. Biotechnol. 32, 1121-1133. doi: 10.1038/nbt. 3033

Rezania, A., Bruin, J. E., Riedel, M. J., Mojibian, M., Asadi, A., Xu, J., et al. (2012). Maturation of human embryonic stem cell-derived pancreatic progenitors into functional islets capable of treating pre-existing diabetes in mice. Diabetes Metab. Res. Rev. 61, 2016-2029. doi: 10.2337/db11-1711

Richardson, T., Barner, S., Candiello, J., Kumta, P. N., and Banerjee, I. (2016). Capsule stiffness regulates the efficiency of pancreatic differentiation of human embryonic stem cells. Acta Biomater. 35, 153-165. doi: 10.1016/j.actbio.2016. 02.025

Robert, T., De Mesmaeker, I., Stangé, G. M., Suenens, K. G., Ling, Z., Kroon, E. J., et al. (2018). Functional beta cell mass from device-encapsulated hESC-derived pancreatic endoderm achieving metabolic control. Stem Cell Rep. 10, 739-750. doi: 10.1016/j.stemcr.2018.01.040

Rocheleau, J. V., Walker, G. M., Head, W. S., McGuinness, O. P., and Piston, D. W. (2004). Microfluidic glucose stimulation reveals limited coordination of intracellular Ca2+ activity oscillations in pancreatic islets. Proc. Natl. Acad. Sci. U.S.A. 101, 12899-12903. doi: 10.1073/pnas.0405149101

Rosado-Olivieri, E. A., Anderson, K., Kenty, J. H., and Melton, D. A. (2019). YAP inhibition enhances the differentiation of functional stem cell-derived insulin-producing $\beta$ cells. Nat. Commun. 10:1464. doi: 10.1038/s41467-01 9-09404-6

Rosenberg, L., Wang, R., Paraskevas, S., and Maysinger, D. (1999). Structural and functional changes resulting from islet isolation lead to islet cell death. Surgery 126, 393-398. doi: 10.1016/S0039-6060(99)70183-2

Rozario, T., and DeSimone, D. W. (2010). The extracellular matrix in development and morphogenesis: a dynamic view. Dev. Biol. 341, 126-140. doi: 10.1016/j. ydbio.2009.10.026

Sabatini, P. V., Speckmann, T., and Lynn, F. C. (2019). Friend and foe: $\beta$-cell $\mathrm{Ca} 2+$ signaling and the development of diabetes. Mol. Metab. 21, 1-12. doi: 10.1016/j.molmet.2018.12.007

Sackett, S. D., Tremmel, D. M., Ma, F., Feeney, A. K., Maguire, R. M., Brown, M. E., et al. (2018). Extracellular matrix scaffold and hydrogel derived from decellularized and delipidized human pancreas. Sci. Rep. 8:10452. doi: 10.1038/ s41598-018-28857-1

Saha, S., Ji, L., de Pablo, J. J., and Palecek, S. P. (2006). Inhibition of human embryonic stem cell differentiation by mechanical strain. J. Cell. Physiol. 206, 126-137. doi: 10.1002/jcp.20441

Samols, E., Marri, G., and Marks, V. (1965). Promotion of insulin secretion by glucagon. Lancet 286, 415-416. doi: 10.1016/S0140-6736(65)90761-0
Sankar, K. S., Green, B. J., Crocker, A. R., Verity, J. E., Altamentova, S. M., and Rocheleau, J. V. (2011). Culturing pancreatic islets in microfluidic flow enhances morphology of the associated endothelial cells. PLoS One 6:e24904. doi: 10.1371/journal.pone.0024904

Schaffer, A. E., Taylor, B. L., Benthuysen, J. R., Liu, J., Thorel, F., Yuan, W., et al. (2013). Nkx6.1 controls a gene regulatory network required for establishing and maintaining pancreatic beta cell identity. PLoS Genet. 9:e1003274. doi: 10.1371/journal.pgen.1003274

Schulz, T. C., Young, H. Y., Agulnick, A. D., Babin, M. J., Baetge, E. E., Bang, A. G., et al. (2012). A scalable system for production of functional pancreatic progenitors from human embryonic stem cells. PLoS One 7:e37004. doi: 10. 1371/journal.pone.0037004

Shapiro, A. M. J., Pokrywczynska, M., and Ricordi, C. (2017). Clinical pancreatic islet transplantation. Nat. Rev. Endocrinol. 13, 268-277.

Sharma, A., Yerra, V. G., and Kumar, A. (2017). Emerging role of Hippo signalling in pancreatic biology: YAP re-expression and plausible link to islet cell apoptosis and replication. Biochimie 133, 56-65. doi: 10.1016/j.biochi.2016.12.009

Shenkman, R. M., Godoy-Silva, R., Papas, K. K., and Chalmers, J. J. (2009). Effects of energy dissipation rate on islets of Langerhans: implications for isolation and transplantation. Biotechnol. Bioeng. 103, 413-423. doi: 10.1002/ bit. 22241

Shih, H. P., Panlasigui, D., Cirulli, V., and Sander, M. (2016). ECM Signaling regulates collective cellular dynamics to control pancreas branching morphogenesis. Cell Rep. 14, 169-179. doi: 10.1016/j.celrep.2015.12.027

Silva, P. N., Green, B. J., Altamentova, S. M., and Rocheleau, J. V. (2013). A microfluidic device designed to induce media flow throughout pancreatic islets while limiting shear-induced damage. Lab Chip 13, 4374-4384. doi: 10.1039/ C3LC50680K

Sipione, S., Eshpeter, A., Lyon, J. G., Korbutt, G. S., and Bleackley, R. C. (2004) Insulin expressing cells from differentiated embryonic stem cells are not beta cells. Diabetologia 47, 499-508. doi: 10.1007/s00125-004-1349-Z

Song, J., and Millman, J. R. (2016). Economic 3D-printing approach for transplantation of human stem cell-derived $\beta$-like cells. Biofabrication 9:015002. doi: 10.1088/1758-5090/9/1/015002

Stendahl, J. C., Kaufman, D. B., and Stupp, S. I. (2009). Extracellular matrix in pancreatic islets: relevance to scaffold design and transplantation. Cell Transplant. 18, 1-12. doi: 10.3727/096368909788237195

Sugimoto, M., Takahashi, S., Kojima, M., Gotohda, N., Kato, Y., Kawano, S., et al. (2014). What is the nature of pancreatic consistency? Assessment of the elastic modulus of the pancreas and comparison with tactile sensation, histology, and occurrence of postoperative pancreatic fistula after pancreaticoduodenectomy. Surgery 156, 1204-1211. doi: 10.1016/j.surg.2014.05.015

Suszynski, T. M., Avgoustiniatos, E. S., and Papas, K. K. (2014). Intraportal islet oxygenation. J. Diabetes Sci. Technol. 8, 575-580. doi: 10.1177/ 1932296814525827

Svendsen, B., Larsen, O., Gabe, M. B. N., Christiansen, C. B., Rosenkilde, M. M., Drucker, D. J., et al. (2018). Insulin secretion depends on intra-islet glucagon signaling. Cell Rep. 25, 1127-1134.e2. doi: 10.1016/j.celrep.2018.10.018

Taipale, J., and Keski-Oja, J. (1997). Growth factors in the extracellular matrix. FASEB J. 11, 51-59.

Takizawa-Shirasawa, S., Yoshie, S., Yue, F., Mogi, A., Yokoyama, T., Tomotsune, D., et al. (2013). FGF7 and cell density are required for final differentiation of pancreatic amylase-positive cells from human ES cells. Cell Tissue Res. 354, 751-759. doi: 10.1007/s00441-013-1695-6

Tao, T., Wang, Y., Chen, W., Li, Z., Su, W., Guo, Y., et al. (2019). Engineering human islet organoids from iPSCs using an organ-on-chip platform. Lab Chip 19, 948-958. doi: 10.1039/C8LC01298A

Taylor-Weiner, H., Ravi, N., and Engler, A. J. (2015). Traction forces mediated by integrin signaling are necessary for definitive endoderm specification. J. Cell Sci. 128, 1961. doi: 10.1242/jcs.166157

Taylor-Weiner, H., Schwarzbauer, J. E., and Engler, A. J. (2013). Defined extracellular matrix components are necessary for definitive endoderm induction. Stem Cells 31, 2084-2094. doi: 10.1002/stem.1453

Toyoda, T., Kimura, A., Tanaka, H., Ameku, T., Mima, A., Hirose, Y., et al. (2017). Rho-associated kinases and non-muscle myosin IIs inhibit the differentiation of human iPSCs to pancreatic endoderm. Stem Cell Rep. 9, 419-428. doi: 10.1016/ j.stemcr.2017.07.005 
Toyoda, T., Mae, S.-I., Tanaka, H., Kondo, Y., Funato, M., Hosokawa, Y., et al. (2015). Cell aggregation optimizes the differentiation of human ESCs and iPSCs into pancreatic bud-like progenitor cells. Stem Cell Res. 14, 185-197. doi: 10.1016/j.scr.2015.01.007

Tran, R., Moraes, C., and Hoesli, C. A. (2020). Controlled clustering enhances PDX1 and NKX6.1 expression in pancreatic endoderm cells derived from pluripotent stem cells. Sci. Rep. 10:1190. doi: 10.1038/s41598-020-57787-0

Trappmann, B., Gautrot, J. E., Connelly, J. T., Strange, D. G. T., Li, Y., Oyen, M. L., et al. (2012). Extracellular-matrix tethering regulates stem-cell fate. Nat. Mater. 11, 642-649. doi: 10.1038/nmat3339

Trimble, E. R., Halban, P. A., Wollheim, C. B., and Renold, A. E. (1982). Functional differences between rat islets of ventral and dorsal pancreatic origin. J. Clin. Invest. 69, 405-413. doi: 10.1172/jci110464

Tschumperlin, D. J., Dai, G., Maly, I. V., Kikuchi, T., Laiho, L. H., McVittie, A. K., et al. (2004). Mechanotransduction through growth-factor shedding into the extracellular space. Nature 429, 83-86. doi: 10.1038/nature02543

Ungrin, M., and Zandstra, P. (2011). Devices and methods for production of cell aggregates. U.S. Patent No US20110086375A1. Washington, DC: U.S. Patent and Trademark Office.

Vegas, A. J., Veiseh, O., Gürtler, M., Millman, J. R., Pagliuca, F. W., Bader, A. R., et al. (2016). Long-term glycemic control using polymer-encapsulated human stem cell-derived beta cells in immune-competent mice. Nat. Med. 22, 306-311. doi: $10.1038 / \mathrm{nm} .4030$

Velazco-Cruz, L., Goedegebuure, M. M., and Millman, J. R. (2020). Advances toward engineering functionally mature human pluripotent stem cell-derived $\beta$ cells. Front. Bioeng. Biotechnol. 8:786. doi: 10.3389/fbioe.2020.00786

Velazco-Cruz, L., Song, J., Maxwell, K. G., Goedegebuure, M. M., Augsornworawat, P., Hogrebe, N. J., et al. (2019). Acquisition of dynamic function in human stem cell-derived $\beta$ cells. Stem Cell Rep. 12, 351-365. doi: 10.1016/j.stemcr.2018.12. 012

Veres, A., Faust, A. L., Bushnell, H. L., Engquist, E. N., Kenty, J. H.-R., Harb, G., et al. (2019). Charting cellular identity during human in vitro $\beta$-cell differentiation. Nature 569, 368-373. doi: 10.1038/s41586-019-1168-5

Walker, J. T., Haliyur, R., Nelson, H. A., Ishahak, M., Poffenberger, G., Aramandla, R., et al. (2020). Integrated human pseudoislet system and microfluidic platform demonstrate differences in GPCR signaling in islet cells. JCI Insight 5:e137017. doi: 10.1172 /jci.insight.137017

Wan, J., Huang, Y., Zhou, P., Guo, Y., Wu, C., Zhu, S., et al. (2017). Culture of iPSCs derived pancreatic $\beta$-like cells in vitro using decellularized pancreatic scaffolds: a preliminary trial. Biomed Res. Int. 2017:4276928. doi: 10.1155/2017/4276928

Wang, C., Baker, B. M., Chen, C. S., and Schwartz, M. A. (2013). Endothelial cell sensing of flow direction. Arterioscler. Thromb. Vasc. Biol. 33, 2130-2136. doi: 10.1161/ATVBAHA.113.301826

Wang, H., Abhilash, A., Chen, C. S., Wells, R. G., and Shenoy, V. B. (2014). Long-range force transmission in fibrous matrices enabled by tension-driven alignment of fibers. Biophys. J. 107, 2592-2603. doi: 10.1016/j.bpj.2014.09.044

Wang, J., Yuan, R., Zhu, X., and Ao, P. (2020). Adaptive landscape shaped by core endogenous network coordinates complex early progenitor fate commitments in embryonic pancreas. Sci. Rep. 10:1112. doi: 10.1038/s41598-020-57903-0

Wang, N., Tytell, J. D., and Ingber, D. E. (2009). Mechanotransduction at a distance: mechanically coupling the extracellular matrix with the nucleus. Nat. Rev. Mol. Cell Biol. 10, 75-82. doi: 10.1038/nrm2594

Wang, Y., Cheng, L., and Gerecht, S. (2014). Efficient and scalable expansion of human pluripotent stem cells under clinically compliant settings: a view in 2013. Ann. Biomed. Eng. 42, 1357-1372. doi: 10.1007/s10439-013-0921-4

Wang, Y., Lo, J. F., Mendoza-Elias, J. E., Adewola, A. F., Harvat, T. A., Kinzer, K. P., et al. (2010). Application of microfluidic technology to pancreatic islet research: first decade of endeavor. Bioanalysis 2, 1729-1744. doi: 10.4155/bio.10.131

Watt, F. M. (1986). The extracellular matrix and cell shape. Trends Biochem. Sci. 11, 482-485. doi: 10.1016/0968-0004(86)90252-5
Weber, L. M., and Anseth, K. S. (2008). Hydrogel encapsulation environments functionalized with extracellular matrix interactions increase islet insulin secretion. Matrix Biol. 27, 667-673. doi: 10.1016/j.matbio.2008.08.001

Wolfenson, H., Yang, B., and Sheetz, M. P. (2019). Steps in mechanotransduction pathways that control cell morphology. Annu. Rev. Physiol. 81, 585-605. doi: 10.1146/annurev-physiol-021317-121245

Wong, J. C. Y., Gao, S. Y., Lees, J. G., Best, M. B., Wang, R., and Tuch, B. E. (2010). Definitive endoderm derived from human embryonic stem cells highly express the integrin receptors $\alpha \mathrm{V}$ and $\beta 5$. Cell Adh. Migr. 4, 39-45. doi: 10.4161/cam.4. 1.10627

Wozniak, M. A., and Chen, C. S. (2009). Mechanotransduction in development: a growing role for contractility. Nat. Rev. Mol. Cell Biol. 10, 34-43. doi: 10.1038/ nrm2592

Wu, J., Rostami, M. R., Cadavid Olaya, D. P., and Tzanakakis, E. S. (2014). Oxygen transport and stem cell aggregation in stirred-suspension bioreactor cultures. PLoS One 9:e102486. doi: 10.1371/journal.pone.0102486

Xin, X., Hussain, M., and Mao, J. J. (2007). Continuing differentiation of human mesenchymal stem cells and induced chondrogenic and osteogenic lineages in electrospun PLGA nanofiber scaffold. Biomaterials 28, 316-325. doi: 10.1016/j. biomaterials.2006.08.042

Yabe, S. G., Fukuda, S., Nishida, J., Takeda, F., Nashiro, K., and Okochi, H. (2019). Induction of functional islet-like cells from human iPS cells by suspension culture. Regen. Ther. 10, 69-76. doi: 10.1016/j.reth.2018.11.003

Yang, M. T., Fu, J., Wang, Y.-K., Desai, R. A., and Chen, C. S. (2011). Assaying stem cell mechanobiology on microfabricated elastomeric substrates with geometrically modulated rigidity. Nat. Protoc. 6, 187-213. doi: 10.1038/nprot. 2010.189

Youngblood, R. L., Sampson, J. P., Lebioda, K. R., and Shea, L. D. (2019). Microporous scaffolds support assembly and differentiation of pancreatic progenitors into $\beta$-cell clusters. Acta Biomater. 96, 111-122. doi: 10.1016/j. actbio.2019.06.032

Yu, Y., Gamble, A., Pawlick, R., Pepper, A. R., Salama, B., Toms, D., et al. (2018). Bioengineered human pseudoislets form efficiently from donated tissue, compare favourably with native islets in vitro and restore normoglycaemia in mice. Diabetologia 61, 2016-2029. doi: 10.1007/s00125-018-4672-5

Yung, T., Poon, F., Liang, M., Coquenlorge, S., McGaugh, E. C., Hui, C., et al. (2019). Sufu- and Spop-mediated downregulation of Hedgehog signaling promotes beta cell differentiation through organ-specific niche signals. Nat. Commun. 10:4647. doi: 10.1038/s41467-019-12624-5

Zhao, L., Mok, S., and Moraes, C. (2019). Micropocket hydrogel devices for all-inone formation, assembly, and analysis of aggregate-based tissues. Biofabrication 11:045013. doi: 10.1088/1758-5090/ab30b4

Zhou, J. X., Brusch, L., and Huang, S. (2011). Predicting pancreas cell fate decisions and reprogramming with a hierarchical multi-attractor model. PLoS One 6:e14752. doi: 10.1371/journal.pone.0014752

Zhou, J. X., Samal, A., d'Hérouël, A. F., Price, N. D., and Huang, S. (2016). Relative stability of network states in Boolean network models of gene regulation in development. Biosystems 142-143, 15-24. doi: 10.1016/j.biosystems.2016.03. 002

Conflict of Interest: The authors declare that the research was conducted in the absence of any commercial or financial relationships that could be construed as a potential conflict of interest.

Copyright (C) 2020 Tran, Moraes and Hoesli. This is an open-access article distributed under the terms of the Creative Commons Attribution License (CC BY). The use, distribution or reproduction in other forums is permitted, provided the original author(s) and the copyright owner(s) are credited and that the original publication in this journal is cited, in accordance with accepted academic practice. No use, distribution or reproduction is permitted which does not comply with these terms. 